2015-05-21

The oppeliid, perisphinctid and aspidoceratid ammonite faunas of the 'Corallian' Beds (Upper Jurassic) in Cambridgeshire, England

\author{
Page, KN
}

http://hdl.handle.net/10026.1/4994

10.1144/pygs2015-355

PROCEEDINGS OF THE YORKSHIRE GEOLOGICAL SOCIETY

All content in PEARL is protected by copyright law. Author manuscripts are made available in accordance with publisher policies. Please cite only the published version using the details provided on the item record or document. In the absence of an open licence (e.g. Creative Commons), permissions for further reuse of content should be sought from the publisher or author. 


\section{Article DOI: 10.1144/pygs2015-355}

\section{Article number: 2015-355}

\section{Article-type: research-article}

\section{Subject: Research article}

\section{Author please note}

Please check this proof carefully for errors, once it is published online no further changes can be made. In particular check that figures, tables and equations are correct.

Please note the new page design for this journal. This will be effective for the Online First version of this article and print copies of the journal from 2015 onward This is an Online First paper. Until issue publication and page numbers are confirmed, please cite this article as: K. N. Page, J. K. Wright \&, S. R. A. Kelly. [year]. The oppeliid, perisphinctid and aspidoceratid ammonite faunas of the 'Corallian' Beds (Upper Jurassic) in Cambridgeshire, England. Scottish Journal of Geology, first published online [month] [date], [year], http://dx.doi.org/10.1144/pygs2015-355 (where square bracketed text should be updated with actual dates)

\section{Author queries (see $\mathrm{AQ}$ ? in margins)}

\begin{tabular}{|l|l|}
\hline No & \multicolumn{1}{|c}{ Query } \\
\hline 1 & John - can you confirm that you are corresponding author please? \\
\hline 2 & "Wright \& Głowniak, 2015, this isn't in the reference list - but only papers that are accepted for publication can be cited \\
\hline 3 & Fig. 6:5 - do you mean Fig. 5? \\
\hline 4 & this cannot be cited if not accepted \\
\hline 5 & should the species be in italics for chronozones? \\
\hline 6 & please give location of publishers \\
\hline 7 & please give publishers \\
\hline 8 & please give publishers \\
\hline 9 & please give publishers \\
\hline 10 & please give publishers \\
\hline 11 & this tabulated information is really a table or Fig. (like Fig. 15) - should we re-work it to make this as such? \\
\hline
\end{tabular}




\title{
The oppeliid, perisphinctid and aspidoceratid ammonite faunas of the 'Corallian' Beds (Upper Jurassic) in Cambridgeshire, England
}

\author{
K. N. Page ${ }^{1}$, J. K. Wright ${ }^{*}$ \& S. R. A. Kelly ${ }^{3}$ \\ ${ }^{1}$ Department of Geology, University of Plymouth, Drake Circus, Plymouth PL4 8AA, UK \\ ${ }^{2}$ Department of Earth Sciences, Royal Holloway University of London, Egham, Surrey, TW20 0EX, UK \\ ${ }^{3}$ CASP, West Building, 181A Huntingdon Road, University of Cambridge, Cambridge, CB3 0DH, UK \\ [A0: 1] * Correspondence: j.wright@es.rhul.ac.uk
}

\begin{abstract}
The Upware Limestone Member comprises an enclave of Middle Oxfordian 'Corallian' facies limestone situated on the East Midlands Shelf within the more typical mudrock-dominated sequences of eastern England, and is assigned to the West Walton Formation. Recent deep excavations in the district have revealed the base of the Upware Limestone, not exposed since the last century, resting on a mudrock sequence, the Dimmock's Cote Marl Member. The Upware Limestone and Dimmock's Cote Marl have yielded an unusually common ammonite fauna, including both Boreal (Cardioceratidae) and Tethyan (Perisphinctinae) elements, and rare Tethyian oppeliids and aspidoceratids. Thirteen nominal species of Perisphinctes are described and figured, as are one species of Neocampylites and one of Euaspidoceras. Three distinct assemblages of Perisphinctes are recognized in the Upware succession. The faunas are correlated with existing zonations for the Middle Oxfordian of Sub-Boreal and Sub-Mediterranean regions, including sub-subzonal schemes (i.e. 'biohorizons'). Such correlations aid the construction of correlative links between two distinct ammonite provinces and have great potential for resolving some of the outstanding questions of European Middle Oxfordian stratigraphy. The succession is also of great importance within Britain as it is the only known locality to yield faunas that are stratigraphically intermediate between the classic Corallian assemblages of Oxford and the later faunas of the Upper Calcareous Grit of Yorkshire.
\end{abstract}

Received 3 July 2014; revised XX XX XX; accepted 25 February 2015

The fossiliferous carbonate succession exposed at Upware, Cambridgeshire, provides a rich, well-localized succession of perisphinctid and cardioceratid ammonites that spans the critical Plicatilis-Transversarium zonal boundary, making this an important area for biogeographical and biostratigraphical studies. The cardioceratids have been the subject of a separate study (Wright \& Page 2006); the remaining ammonite fauna is described here. This paper sets the oppeliid, perisphinctid and aspidoceratid faunas of newly exposed beds in the context of the extensive museum collections of similar ammonites collected over many years from higher beds.

The 'Corallian' facies rocks of Upware crop out in a narrow, low-lying ridge that stretches for some $6 \mathrm{~km}$ along the eastern side of the River Cam (Fig. 1) and rises only 5 to $10 \mathrm{~m}$ above the surrounding fens. The rocks largely consist of relatively soft, poorly cemented limestones, the Upware Limestone of Wright et al. (2000) and Wright \& Page (2006). Only two exposures remain of those formerly visible and listed by Wright et al. (2000). Commissioners' Pit [TL 539 708] is at present well exposed, being actively maintained by the Upware Field Studies Centre, Cambridgeshire County Council. Dimmock's Cote Quarry [TL 545 724] has been worked by the Wicken Lime \& Stone Co., though work here is now on a lesser scale than before.

\section{The 'Corallian' succession at the Dimmock's} Cote Quarry

The 'Corallian' succession at Upware has long been known for its Middle Oxfordian ammonite fauna, some of which was figured by Arkell (1935-1948). The succession as then understood was described in detail by Kelly (1985). In 1993, quarrying began at a deeper level at Dimmock's Cote Quarry, exposing a $0.6 \mathrm{~m}$ thick bed of limestone, the Crinoid Bed of Wright et al. (2000), which has yielded numerous Perisphinctes spp. and Cardioceras spp. Trial holes and drainage ditches in the base of the pit revealed several metres of underlying marls with calcareous concretions that had never been exposed previously at Upware. These were named the Dimmock's Cote Marl by Wright et al. (2000). A fauna of Perisphinctes spp. and Cardioceras spp. which differs in important aspects from that found in the beds above was collected. The faunal succession at Dimmock's Cote Quarry is thus of considerable importance in attempts to unravel the complicated history of the Tethyan perisphinctid and Boreal cardioceratid faunas in the British Middle Oxfordian. Detailed measured sections, faunal lists and a discussion of the manner of deposition of the whole Upware succession were published by Wright et al. (2000). A summary of the succession as seen in Dimmock's Cote Quarry is given in Figure 2; the lithologies of the various beds are as follows (informal lithostratigraphic subdivisions in brackets):

\section{Preservation of the Sponge Bed and Crinoid Bed ammonites}

As noted by Wright et al. (2000), the Sponge Bed and Crinoid Bed together form a tempestite, their fauna 
UPWARE LIMESTONE MEMBER m

(9) Cream-coloured, soft, fossiliferous, pisolitic oobiomicrite with a rich bivalve-gastropod fauna, and frequent ammonites. $3-5$

CORAL BED

(8)

Coarse, bioclastic, coral-rich limestone seen at the western end of the pit, and containing a prolific bivalve-gastropod-

(7) echinoid-coral fauna.

CRINOID BED

$(6 \mathrm{c})$

Grey, relatively soft, marly pisolite, weathering pale cream; echinoids are common in a band near the top.

Pale grey biomicrite containing macroconch perisphinctids and cardioceratids with the phragmocones not infilled; hollow apart from sparry calcite.

(6b) Medium grey, coarse biomicrite containing a poorly preserved micrite-infilled ammonite fauna and numerous bivalves

SPONGE BED

(6a) and echinoids.

DIMMOCK'S COTE MARL MEMBER

\begin{tabular}{llc} 
(5) & Dark grey mudrock with a poorly preserved cardioceratid ammonite/bivalve fauna. \\
(4) & Grey, argillaceous limestone containing large perisphinctid fragments. & 0.6 \\
(3) & Dark grey mudrock with occasional bivalves and an impersistent, argillaceous limestone. \\
(2) & Grey, argillaceous, spicular, shelly limestone with poorly preserved ammonites and bivalves. & $0.1-0.15$ \\
(1) & Dark grey mudrock with scattered bivalves and a large perisphinctid preserved in a concretion. & $0.3-0.4$ \\
\hline
\end{tabular}

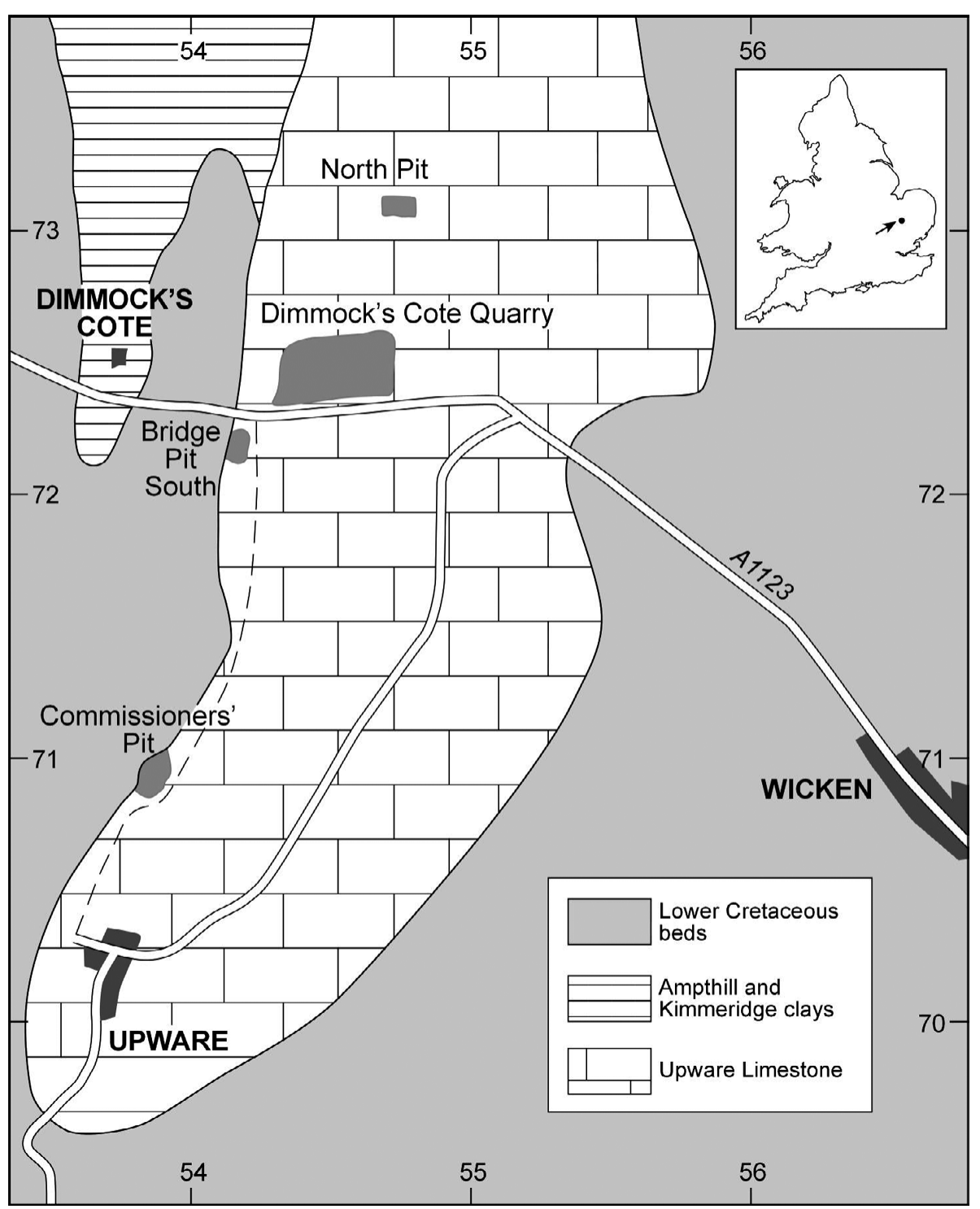

Fig. 1. Geological and topographical map of the Upware area, after Wrigh \& Page (2006), showing locations of quarries exposing the Upware Limestone. National Grid co-ordinates at $1 \mathrm{~km}$ spacings. potentially comprising members of a living population plus deceased individuals suddenly swept together by a storm. As such, many more immature, juvenile ammonites are present than is usual. Also, dissolution of the shells took place while the sediment was still soft, leaving a thin carbonaceous film marking the outline of the shell. Though the specimens are often easily extracted from the matrix, it can be very difficult to make out septa, even with a binocular 
Ammonite faunas of the Corallian Beds, Cambridgeshire

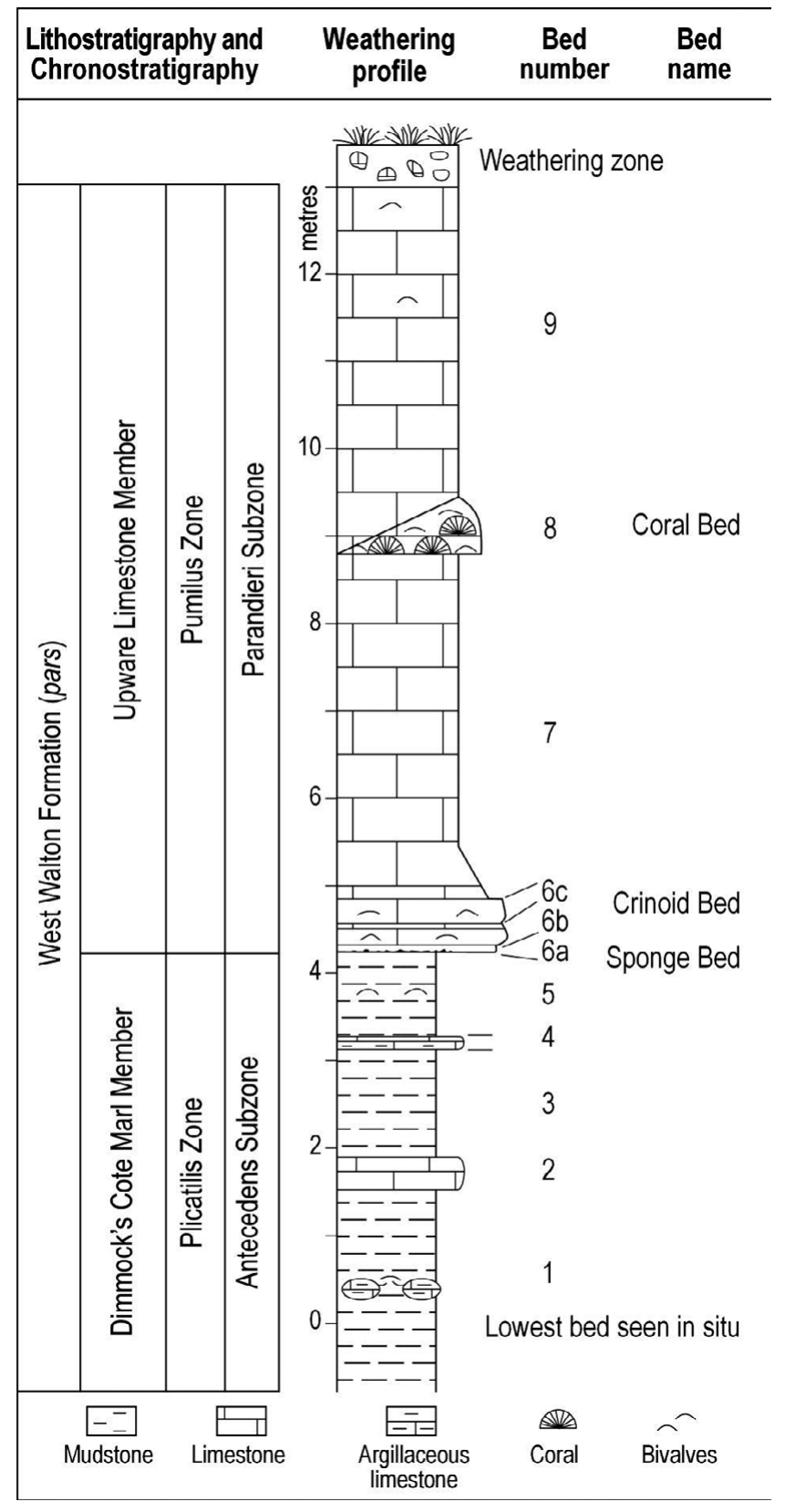

Fig. 2. Summary of the lithological succession at Upware, after Wright et al. (2000).

microscope, or, if septa are visible, to decide whether the final ones are crowded, signifying a mature adult. Thus, in the frequent absence of the aperture or of noticeable uncoiling, the adult status of many specimens is uncertain.

\section{Repository of speciments, conventions and localities}

All ammonites studied, including those newly collected by the authors, are in the collection of the Sedgwick Museum, Cambridge (CAMSM, abbreviated to SM here). All specimens from the Dimmock's Cote Marl and all the authors' specimens from the Upware Limestone were collected from Dimmock's Cote Quarry, previously known as Bridge Pit North [TL 545 724]. Most previously collected specimens from the Upware Limestone in the Sedgwick Museum collection came from quarries in this area that no longer exist, particularly North Pit [TL 544 728] and Bridge Pit South [TL 542 722]. The pits formerly known as New Pit and Bridge Pit were close together and, according to Arkell (1937b), these names were used interchangeably. Both pits seem to have been later subsumed into Dimmock's Cote Quarry. Some specimens were also collected from the quarry near Upware formerly known as South Pit, and now known as Commissioners' Pit [TL 539 708].

Ammonite measurements: whorl height, whorl breadth and umbilical width are given conventionally as proportions of the shell diameter at which measurements were made. Where specimens have bold ribbing, the breadth given is that between high points of the ribs, with the breadth in between ribs given in brackets. The following abbreviations are used:

$\mathrm{D}(\mathrm{phg})=$ diameter at final septum

$\mathrm{D}(\mathrm{ad})=$ diameter of adult with uncoiling and/or crowding of final septa

$\mathrm{D}(\mathrm{juv})=$ diameter of complete juvenile

$\mathrm{D}(\max )=$ maximum diameter preserved

$0 . \mathrm{x}$ wh $\mathrm{bch}=$ fraction of body-chamber preserved as a proportion of the whorl

$\mathrm{rpw}=$ ribs per whorl

\section{Systematic Palaeontology}

\section{Order Ammonoidea Zittel, 1882}

The following sequence of ammonite faunas, listed as 'nominal' species (see discussion below), is recognizable in the Upware district, primarily in Dimmock's Cote Quarry $([\mathrm{M}]=$ macroconch, $[\mathrm{m}]=$ microconch $)$ :

Beds 7 and $9(*=$ specimens in pre-existing Sedgwick Museum collections identified as being from Bed 9 by matrix): Cardioceras (Maltoniceras) maltonense (Young \& Bird), C. (Miticardioceras) tenuiserratum (Oppel)*, C. (M.) aff. sopotense (Malinowska), C. (Subvertebriceras) densiplicatum Boden*, C. (S.) zenaidae Ilovaisky*, Perisphinctes (P.) holtonensis Buckman $[\mathrm{M}]^{*}$, P. (P.) chloroolithicus Gümbel [M]*, P. (Dichotomosphinctes) aff. dobrogensis Simionescu [m]*, Aspidoceras (Euaspidoceras) sp. aff. paucituberculatum Arkell* and Neocampylites sp. aff. henrici (d'Orbigny)*.

Beds 6a (Sponge Bed) and 6b-6c (Crinoid Bed): Cardioceras (Cawtoniceras) cawtonense (Blake \& Hudleston), C. (Maltoniceras) highworthense Arkell, C. (M.) maltonense, C. (Miticardioceras) aff. sopotense, C. (Scoticardioceras) excavatum (J. Sowerby), C. (Subvertebriceras) densiplicatum, C. (S.) zenaidae, Perisphinctes (P.) parandieri de Loriol [M], P. (P.) tumulosus Buckman [M], P. (Kranaosphinctes) sp. aff. decurrens Buckman $[\mathrm{M}], P$. (Dichotomosphinctes) antecedens Salfeld [m], P. (D.) buckmani Arkell [m] and P. (Otosphinctes) sp. A $[\mathrm{m}]$.

Beds 1-5 (Dimmock's Cote Marl, upper part): Cardioceras (Cawtoniceras) cawtonense, C. (Miticardioceras) tenuiserratum, C. (M.) sopotense, C. (Subvertebriceras) zenaidae, Neocampylites sp. aff. henrici, P. (Kranaosphinctes) ariprepes (Buckman) [M], P. (K.) sp. aff. maximus (Young \& Bird) [M], P. (Otosphinctes) cf. arkelli Głowniak [m] and $P$. (Otosphinctes) cf. ouatius Buckman [m]. 


\section{Superfamily Haploceratoidea Zittel 1884 \\ Family Oppelidae Bonarelli 1894 \\ Subfamily Ochetoceratinae Spath 1928 \\ Genus Neocampylites Callomon 1973}

\section{Type species: Ammonites delmontanus Oppel 1863, designated by Callomon 1973, p. 1003. \\ Neocampylites sp. aff. henrici (d'Orbigny) (Fig. 13B)}

Material. Two specimens from ?Bed 4, Dimmock's Cote Marls (SM X.50139.32, -.62) and three specimens from Bed 9, Upware Limestone (SM J68503, SM J68916, SM X18021), all from Dimmock's Cote Quarry. All specimens are fragments of septate macroconch inner whorls.

Description. When first seen, between 15 and $20 \mathrm{~mm}$ diameter, the shell is smooth. At $25 \mathrm{~mm}$, traces of falcoid secondary ribs are present on the outer half of the whorl side and beyond a spiral raised area, giving an Oxycerites-like appearance. The venter has a sharp median keel and very narrow shoulders. The secondary ribs appear to fade by $67 \mathrm{~mm}$ diameter and the maximum septate diameter observed is around $75 \mathrm{~mm}$ in SM J68916, suggesting a maximum size of at least $100 \mathrm{~mm}$ (allowing for half a whorl of body-chamber).

Discussion. The Upware form appears to be different from the species described by Arkell (1943, pp. 265-268) from the 'Elsworth Rock' and the 'St Ives Rock' (West Walton Formation), under the names $O$. (O.) canaliculatum (von Buch) var. hispidum (Oppel) (Arkell 1943, pl. 60, figs 1, 2), O. (Campylites) henrici (d'Orbigny) (Arkell 1943, pl. 60, figs 3-6) and $O$. (Trimarginites) arolicum (Oppel) (Arkell 1943, pl. 60, fig. 7). Arkell's specimens appear to have stronger ribbed inner whorls and apparently lack the distinctive Oxycerites-like secondary ribbing on their middle whorls. Although none of the specimens recorded by Arkell were collected in situ, additional and comparable material has now been recovered in situ from the Elsworth Rock Member at Papworth Everard (Page 1986). The associated ammonite fauna at Papworth, although stratigraphically condensed, includes many cardioceratids and perisphinctids typical of lower stratigraphic levels than Bed 9, thereby suggesting that the Elsworth Rock Ochetoceras, at least, may represent a slightly older species.

Specimen SM X18021 has a broad resemblance to the type of $O$. (Neocampylites) henrici (d'Orbigny 1850) as refigured by Enay \& Gauthier in Fisher (1994, pl. 73, fig. 5), but the latter has slightly closer secondary ribbing. The type of $O$. henrici is stated to be from the Antecedens Subzone of Précy (Yonne) in France (Enay \& Gauthier in Fisher 1994) and is therefore of broadly similar age to the Upware species.

\section{Superfamily Perisphinctoidea Steinmann, 1890 \\ Family Perispinctidae Steinmann, 1890 Subfamily Perisphinctinae Steinmann, 1890}

Notes on perisphinctid taxonomy. As discussed extensively elsewhere (e.g. Callomon 1963, 1981, 1985; Makowski 1963, 1971; Kennedy \& Cobban 1976; Lehman 1981; Dommergues et al. 1996; Page 2008), ammonite biospecies were sexually dimorphic. The dimorphs are primarily separable by size, with large forms (macroconchs) presumed to be female and small forms (microconchs) male. A difference in mature shell ornament is also typical, and the microconchs of the Perisphinctina (sensu Besenov \& Michailova 1983; Page 1996) typically have paired lateral apertural projections (lappets) and the macroconchs simple curved apertures. Each dimorph also shows a range of ornament strength and whorl section, with round-whorled, coarse-ribbed and more compressed, finer-ribbed extremes being typical.

In the Perisphinctinae, as in many other ammonoid groups, each of these variants has typically been assigned a different specific name and the two members of dimorphic pairs are often placed in different subgenera. The great variability of perisphinctids in particular expressed by this traditional morphological classification can, however, confuse true biological relationships between the preserved members of a biological population. Taken to its extreme, this traditional approach led to an expression of despair by W. J. Arkell during compilation of his famous monograph of British Corallian ammonites: "The present study has shown again how ammonite material if sufficiently plentiful, will defeat any attempt at classification, however "natural" and well balanced its author may consider it to be" (Arkell 1948, p. 380; Callomon 1985, p. 55). Though Arkell was scrupulous in his desire to describe only valid species of ammonite, subsequent ammonite workers have regarded him as a 'splitter' having little regard for the concept of variation within a species (Kennedy 2006). This comment is perhaps a little unkind, as Arkell did, for instance, introduce many new varieties of pre-existing species of cardioceratids to cover such variation in that family. However, he named only two varieties of pre-existing species of Perisphinctes, preferring to introduce many new species names for variants within such macroconch 'genera' as Kranaosphinctes (including Arisphinctes) and Perisphinctes s.s., and microconchs within Dichotomosphinctes and Otosphinctes. Many of these 'species' are almost certainly simply variants within a single evolving biospecies.

As the reasoning behind the concept of sexual dimorphism in ammonites became increasingly accepted, Cope (1967) was the first to accord dimorphs the same specific name through a lineage of perisphinctids. In this manner, Chandler \& Callomon (2009) described a large collection of graphoceratid ammonites from a single horizon in the Aalenian of Dorset, SW England, and showed that this assemblage, which varies considerably in morphology, consists of the macroconchs and microconchs of a single very variable biospecies. A new biospecific name, Leioceras comptocostosum Chandler \& Callomon, was introduced to encompass this assemblage, with pre-existing morphospecies being regarded as varieties of the new biospecies. Subsequently, Wright (2012) described a fauna of cardioceratids from the Lower Oxfordian of the Isle of Skye, again showing that almost all named morphospecies are simply variants of one biospecies. A similar conclusion was reached concerning a separate population of Lower Oxfordian cardioceratids from North Yorkshire.

Returning to the perisphinctids, surely it should now be possible to abandon Arkell's scheme and introduce a scheme 
of transient biospecies, grouping morphospecies and morphosubgenera together into a succession of biological populations. Before introducing a new scheme, however, it is necessary to decide on the extent to which the assemblage of perisphinctids from Upware is likely to be endemic and composed of biologically related animals, i.e. a 'biospecies', or ademic and comprising unrelated specimens brought together by post-mortem drift, with several biospecies likely to be present. Fernandez-Lopez (1995) and Meléndez et al. (2009) have proposed criteria whereby these two alternatives can be distinguished. Studies of Sub-Mediterranean perisphinctids by these authors have shown that ademic ammonite assemblages are characterized by a dominance of mature macroconchs with far fewer microconchs and juveniles. Endemic populations, where individuals are likely to be closely related, are typically characterized by a mixed assemblage of macroconchs, microconchs and juveniles, with macroconchs in the minority.

Wright \& Głowniak (in prep. 2015 show that the perisphinctid fauna of the Upper Oxfordian Clavellata Member (Corallian Group) of Dorset is dominated by macroconchs (50 macroconchs, 16 microconchs), and is likely to be an ademic assemblage in which representatives of a number of biospecies are present. In contrast, the fauna of the Crinoid Bed at Upware is dominated by microconchs (13 microconchs, 9 macroconchs) and is likely to be an endemic assemblage of related specimens.

Given that the fauna of the Crinoid Bed (beds $6 b-c$ ), in particular, appears consistent with it being one contemporaneous population, represented by a full range of macroconchs and microconchs that almost certainly all belong to one biospecies, it might be thought that we should introduce one biospecific name for this assemblage. However, only when a number of important criteria are met can this procedure be convincingly applied. Chandler \& Callomon (2009) noted that:

(1) The assemblage should be isochronous, something that almost certainly applies to the Upware Crinoid Bed fauna.
(2) There should be sufficient specimens to show a seamless integration of characters between them. This is not the case with the Crinoid Bed fauna, where there are gaps in morphology between groups of specimens that may or may not have been filled in life.

(3) The assemblage to be tested for morphological integration should be adult. As mentioned above, many of the Crinoid Bed microconchs are juvenile or are not sufficiently well preserved to enable the maximum adult size to be determined. Głowniak (2002) has shown how essential it is to have this data, the maximum size of microconchs increasing steadily with time during the Middle Oxfordian. Crinoid Bed macroconchs can also be juvenile, or are frequently poorly preserved, lacking the outermost whorl.

Thus, reluctantly, we eschew the possibility of describing this fauna as a biospecies and, as recommended by Chandler \& Callomon (2009), when the criteria are not met, pre-existing morphospecific names are retained. In the present work, the use of subgenera will follow that of Glowniak (2002) and the reader is referred to that work for a definitive discussion of valid perisphinctid subgeneric divisions. Głowniak’s (2002) analysis of Polish Middle Oxfordian perisphinctids was based on the recognition of distinct lineages. However, she was dealing with a succession of faunas that is largely older stratigraphically than the Upware succession, living in an area situated much closer to, and liable to the influx of, Mediterranean populations with their separate lineages. We suggest that, at Upware, we are only dealing with one lineage, within which the proportions of the contained morphotypes varied with time. Effectively, this is a succession of biospecies, each evolving from the previous one.

Microconch adults of Otosphinctes and Dichotomosphinctes complete with aperture are rare in the Upware faunas, and thus maximum size, as used by Glowniak (2002), is not a criterion that can be applied to subdivide the Upware microconchs into successive species and sub-species. However, an attempt has been made to use graphical plots

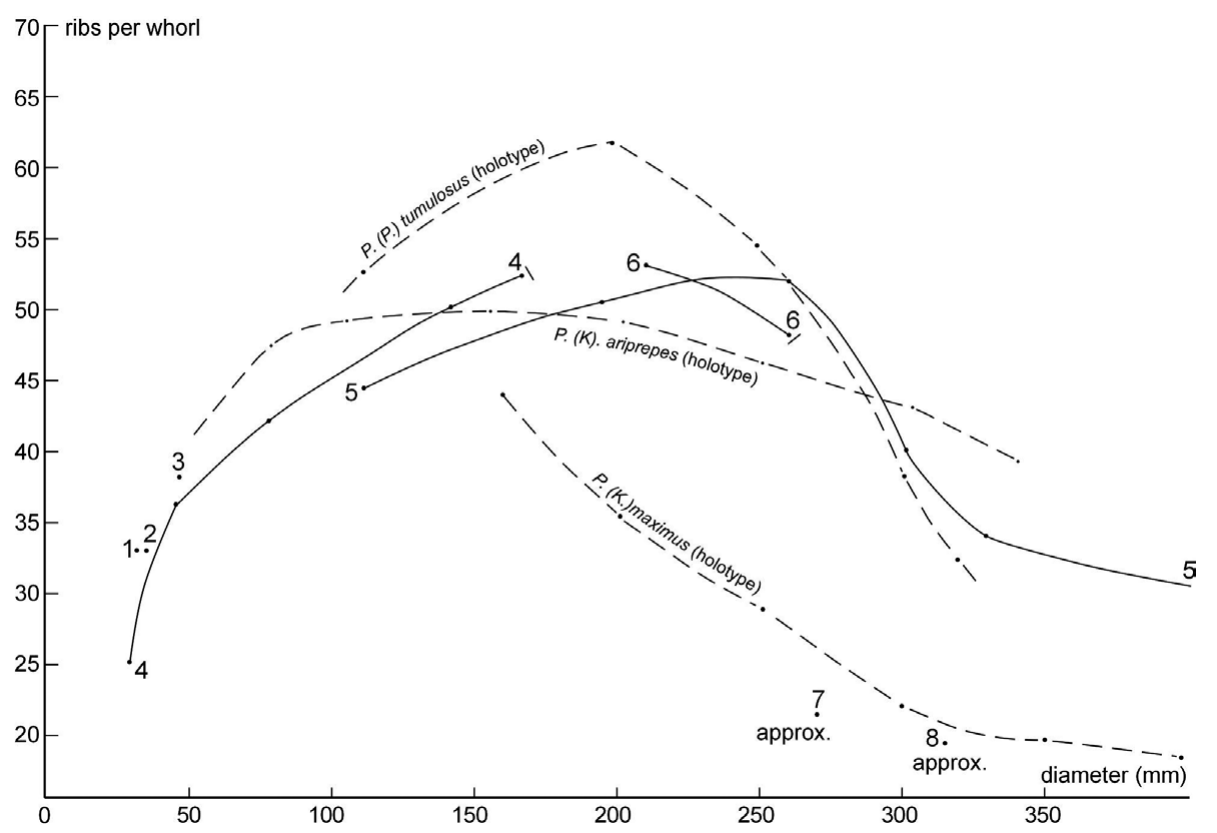

Fig. 3. Rib curves of perisphinctids from the Dimmock's Cote Marl. 1, Perisphinctes (Otosphinctes) cf. ouatius Buckman; 2-3, P. (O.) cf. arkelli Głowniak; 4-6, P. (Kranaosphinctes) ariprepes Buckman; 7-8, $P$. (Perisphinctes) aff. maximus (Young \& Bird). 1, SM X.50139.63; 2, SM X.50139.76; 3, SM X.50139.37; 4, SM X.50139.35; 5, SM X.50139.97; 6, SM X.50139.89; 7, SM X.50139.60; 8, SM X.50139.61. 
K. N. Page et al.

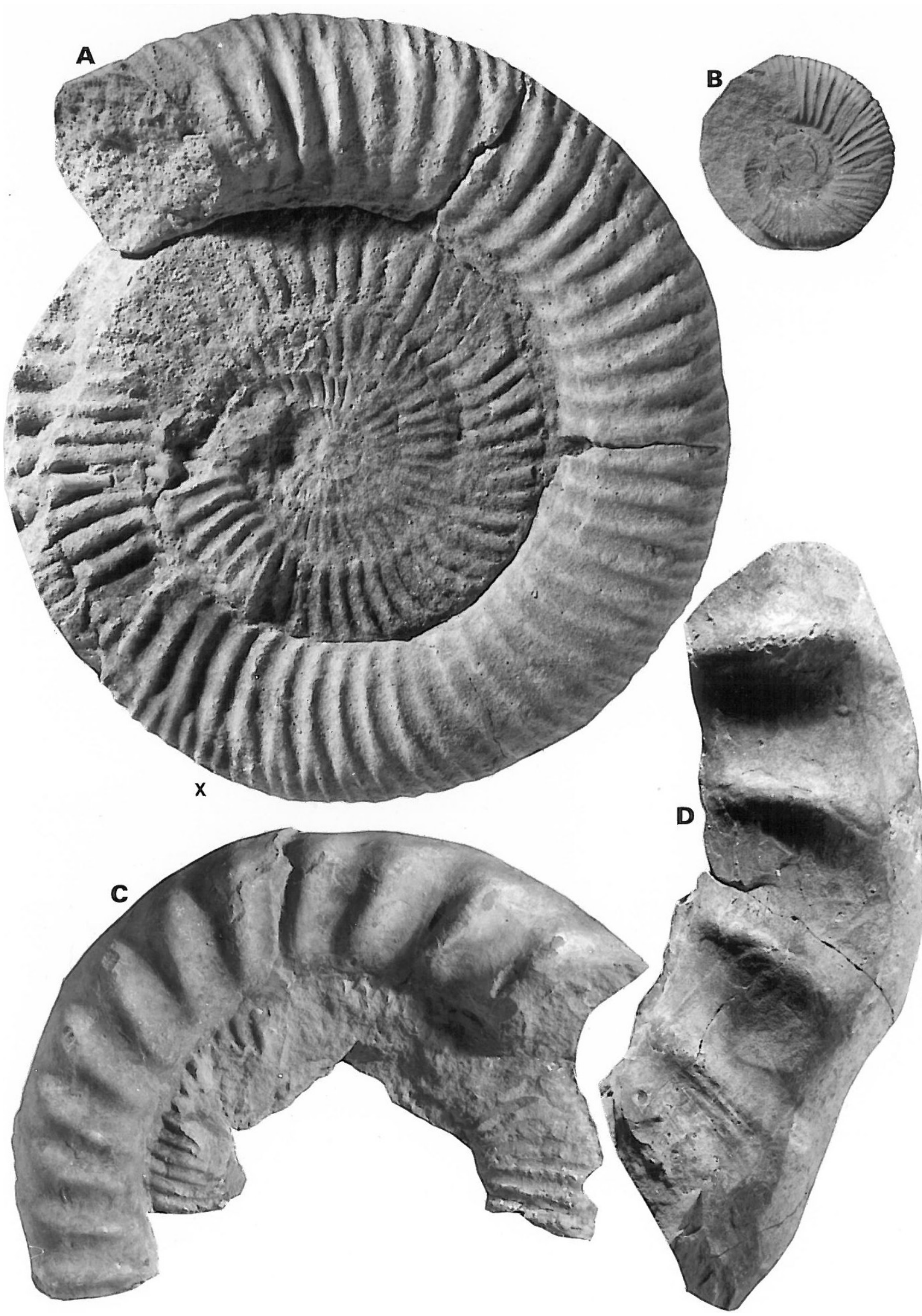


of dimensions and rib counts of the microconchs to separate distinct morphological groups. Within the macroconchs Kranaosphinctes and Perisphinctes s.s., statistical analysis is not possible, and morphospecific variants have been chosen to describe the range of variability present. The rib-density, including the rate of decrease in rib numbers per whorl with increasing shell diameter on variocostate macroconch final whorls, is a useful character for comparison with the macroconchs recorded by Arkell (1935-1948). Graphs representing each successive assemblage are included herein. Some rib numbers have been estimated, as not all specimens show completely preserved whorls. Several juvenile macroconchs have been collected but these are less informative.

Thus, within the whole Upware succession, we describe a series of successive populations, using established subgeneric and specific names to demonstrate the changes in the proportions of these morphotypes with time. The morphospecific names used here should only be taken as guides, the nature of the variation of the assemblage being more diagnostic as illustrated by the figured specimens.

Genus Perisphinctes Waagen 1869

Subgenus Perisphinctes Waagen 1869

Type species. Ammonites variocostatus Buckland 1836, designated by Arkell 1937, p. liii.

Perisphinctes (Perisphinctes) tumulosus Buckman

(Fig. 10C,D,F)

1927 Perisphinctes tumulosus sp. nov.; Buckman, pl. 714.

$1936 b$ Perisphinctes (Perisphinctes) tumulosus Buckman; Arkell, pp. 166, 173.

1938 Perisphinctes (Perisphinctes) chloroolithicus

(Gümbel); Arkell, pl. 18, figs 1a, b, 5a, b, text fig. 25.

Material. Six specimens, SM X.50139.79, -.86, -.90, -.91, $-.94,-.96$, from the Upware Limestone, Crinoid Bed (beds $6 \mathrm{~b}-\mathrm{c})$, all showing portions of the body-chamber, with the inner ribbing poorly seen.

Measurements. SM X.50139.91 (not figured): D (ad) $c$. $280 \mathrm{~mm}$; at $265 \mathrm{~mm}, 0.21,0.28(0.20), 0.58$, ribs $c .48$ at $88 \mathrm{~mm}$, c. 53 at $140 \mathrm{~mm}$, c. 59 at $210 \mathrm{~mm}$.

SM X.50139.96 (Fig. 10C,D): D (phg) $350 \mathrm{~mm}$, D (ad) $460 \mathrm{~mm}$; at $370 \mathrm{~mm}, 0.20,0.34(0.23), 0.65$; ribs $c .58$ at $75 \mathrm{~mm}$, c. 60 at $192 \mathrm{~mm}$, c. 44 at $305 \mathrm{~mm}, c .17$ at $450 \mathrm{~mm}$.

Description. Giant forms, some mature at around $460 \mathrm{~mm}$ diameter (Fig 10C,D) with just over half a whorl of bodychamber (septate to around $350 \mathrm{~mm}$ ). The maximum size is very variable, and two specimens (SM X.50139.91, -.94; Fig. 10F) are apparently mature at only $300 \mathrm{~mm}$, as is the holotype (Buckman 1927, pl. 714). The inner whorls are typically evolute, closely, sharply and regularly ribbed, with only faint, infrequent constrictions present. There are typically around 53 to 60 ribs on the final whorl before variocostation begins. There is then only a steady fall in the rib curve from $60 \mathrm{rpw}$ at $200 \mathrm{~mm}$ to $20 \mathrm{rpw}$ at $460 \mathrm{~mm}$ (Fig. 6).

The whorl section is flat sided up to $200 \mathrm{~mm}$, when a rounded whorl section develops. Secondary ribs initially persist at this stage, as variocostation develops, but suddenly fade, and the venter becomes flat and smooth. The early part of the body chamber has widely spaced primary ribs and a rectangular section with a flattened venter. The final part of the body chamber, towards the mature aperture, develops a rounder section with more frequent ribs (Fig. 10C,D). This change in SM X.50139.94 (Fig. 10F) begins at about $220 \mathrm{~mm}$; it is the coarsely ribbed stage that is much shorter in this specimen.

Remarks. The rib curve of the Upware specimens (Fig. 6) matches that of $P$. tumulosus quite closely. There is much less resemblance to P. parandieri de Loriol (e.g. Arkell 1938, text figs 28, 30, 31) and the neotype (Enay 1966, pl. 6). Though there is a similar ventral flattening of the whorl just before the end of septation so that the whorl breadth here is twice the whorl height, the ridge-ribs on the outer whorl are not as bold as in P. parandieri and are much more numerous.

Perisphinctes (Perisphinctes) parandieri de Loriol (Fig. 11A-D)

1899 Perisphinctes de Riazi Siemiradzki (nom. nov. for P. subrota de Riaz, 1898, p. 31, pl. 14, non Choffat, 1893).

1903 Perisphinctes parandieri de Loriol, pars, pl. 7 (lectotype selected by Buckman, 1924, pl. 511B), non pl. 8.

1927 Martelliceras orientale Buckman, pl. 736A, B. 1939 Perisphinctes (Perisphinctes) parandieri de Loriol; Arkell pp. 95, 97, text figs 28, 30, 31.

1963 Perisphinctes (Perisphinctes) parandieri de Loriol; Malinowska, pp. 157-158, pls 39, 40.

1966 Perisphinctes (Perisphinctes) parandieri de Loriol; Enay, pp. 357-363, pl. 5, figs 1-2.

Material. Two specimens (SM X.50139.92, -.95) from the Upware Limestone, Crinoid Bed (beds 6b-c).

Measurements. SM X.50139.92 (Fig. 11A,B); D (max) c. $300 \mathrm{~mm}$. D (phg) $215 \mathrm{~mm}$; at $230 \mathrm{~mm}, 0.14,0.30(0.25)$, 0.67 ; ribs 53 at $150 \mathrm{~mm}, 54$ at $180 \mathrm{~mm}, c .38$ at $230 \mathrm{~mm}, c$. 31 at $255 \mathrm{~mm}$. 
K. N. Page et al.

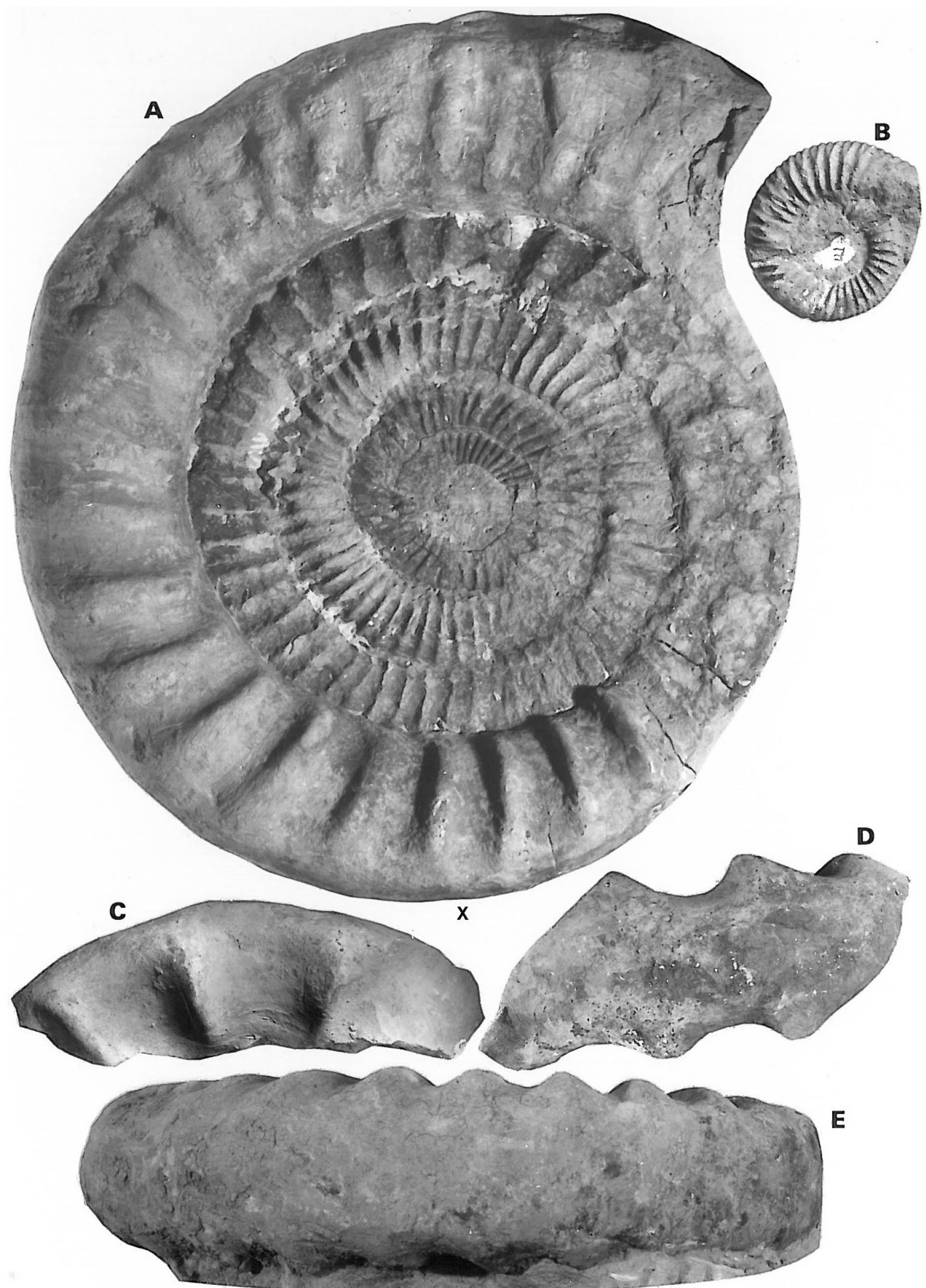

Fig. 5. P. (Otosphinctes) and P. (Kranaosphinctes) from the Dimmocks Cote Marl. (A, E) Perisphinctes (Kranaosphinctes) ariprepes (Buckman)

[M]; SM X.50139.97; almost complete specimen, aperture broken away, inner whorls slightly crushed, Bed $1 ; \times 0.41$. (B) P. (Otosphinctes) cf. ouatius Buckman, SM X.50139.63. (C, D) Perisphinctes (Kranaosphinctes) aff. maximus (Young \& Bird) [M]; SM X.50139.60; fragment of body-chamber; 


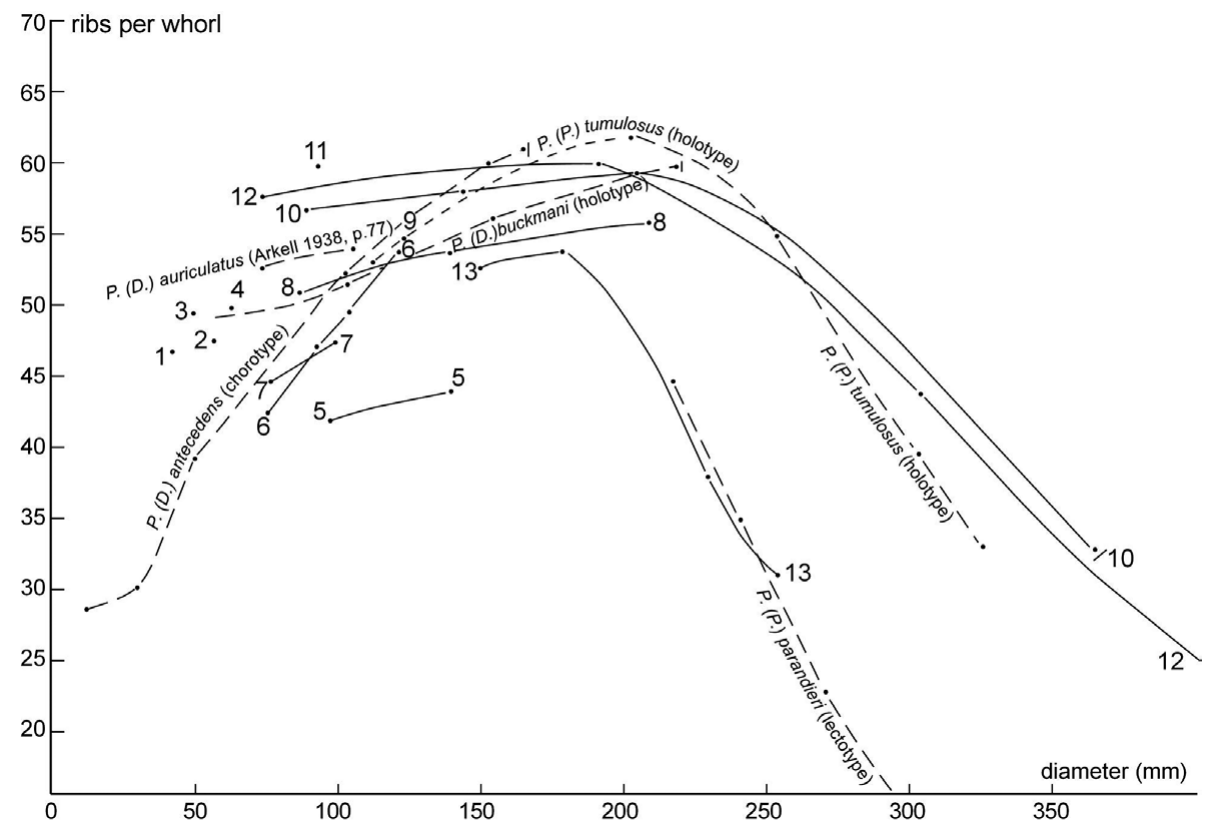

Fig. 6. Rib curves of perisphinctids from Bed 6 the Upware Limestone, Dimmock's Cote Quarry. 1, 3-4, 11, P. (Dichotomosphinctes) buckmani Arkell. 2, P. (Otosphinctes) sp. 5, P. (Kranaosphinctes) aff. decurrens Buckman. 6-7, 9, Perisphinctes (D.) antecedens Salfeld. 8, 10, 12, $P$. (P.) tumulosus Buckman. 13, P. (P.) parandieri de Loriol. 1, SM X.50139.53; 2, SM X.50139.26; 3, SM.X.50139.47; 4, SM.X.50139.71; 5, SM X.50139.28; 6, SM X.50139.87; 7, SM X.50139.44; 8, SM X.50139.91; 9, SM X.50139.29; 10 , SM.X.50139.94; 11, SM X.50139.42; 12 , SM X.50139.96; 13, SM X.50139.92.

Description. Large forms, mature at over $350 \mathrm{~mm}$ diameter. The innermost whorls are not well exposed in the present specimens, but the rib curve appears to rise gently up to $180 \mathrm{~mm}$, when it falls off rapidly (Fig. 6). The early whorl is relatively compressed with flat whorl sides (Fig. 11B). Ribbing is typically biplicate, branching at around $80-83 \%$ of the whorl height and with a noticeable forward slant when viewed laterally.

Variocostation takes place over half a whorl between 180 and $230 \mathrm{~mm}$ diameter and is extreme, producing widely spaced ridge-ribs before the end of septation. These sharp, gently curving ribs may be opposite each other (Fig. 11A), or may alternate in a zig-zag fashion (Fig. 11D). The whorl section at this stage is typically ventrally flattened with a broad, flat venter. Rib numbers plummet to only 17 at around $355 \mathrm{~mm}$ diameter (Fig. 6). The rib curve (Fig. 6:13) of SM X.50139.92 (Fig. 11A,B) matches very closely that of the lectotype.

Discussion. De Loriol (1903) figured two specimens as the new species $P$. parandieri. According to Arkell (1939, p. 106), these are so distinct from each other that they cannot be conspecific. Buckman (1924, pl. 511B) designated de Loriol's specimen with coarser ribbing on the inner whorls (de Loriol 1903, pl. 7) as lectotype. Enay (1966, pl. 5, fig. 3) designated the finely ribbed variant as "morphotype densicosté".

\section{Perisphinctes (Perisphinctes) chloroolithicus (Gümbel)} (Figs 11G, 13E, 14B,D)

1865 Ammonites chloroolithicus Gümbel, p. 49.

1891 Perisphinctes chloroolithicus Gümbel, p. 121. 1912 Perisphinctes chloroolithicus (Gümbel); Klebelsberg, p. 197, pl. 18, figs 4a, b.

1930 Perisphinctes chloroolithicus (Gümbel); Dorn, p. 131, pl. 4, figs 1-3.
1938 Perisphinctes (Dichotomosphinctes) buckmani Arkell; Arkell, pl. 14, fig. 2.

1938 Perisphinctes (Perisphinctes) chloroolithicus (Gümbel); Arkell, pp. 95-104, pl. 18, figs 1-7, pl. 19, fig. 4, text figs 26, 27.

1966 Perisphinctes cf. chloroolithicus (Gümbel); Enay, pp 363-366, pl. 5, figs 4a, b.

Material. Three specimens: SM J359 (North Pit), SM J374 'South Pit', SM J3836 'New Pit', from Bed 9 by matrix, plus numerous inner whorl fragments not identifiable as micro or macroconchs; SM J380 ('Bridge Pit'), SM J41877 and SM X. 50139.39 (Dimmock’s Cote Quarry).

Measurements. SM J359 (Fig. 11G): D (phg) 150mm; at $153 \mathrm{~mm}, 0.26,0.20,0.52$; ribs c. 61 at $93 \mathrm{~mm}, 57$ at $153 \mathrm{~mm}$.

SM J3836 (Fig. 14B); D ( $\max ) 353 \mathrm{~mm}$; ribs 60 at $180 \mathrm{~mm}$, 50 at $200 \mathrm{~mm}, 47$ at $250 \mathrm{~mm}, 30$ at $300 \mathrm{~mm}, 17$ at $353 \mathrm{~mm}$.

Description. Gümbel's holotype comprises only the inner whorls (Arkell 1938). These are densely ribbed, the rib curve rising rapidly from $30 \mathrm{rpw}$ at $40 \mathrm{~mm}$ to $60-64 \mathrm{rpw}$ at $160 \mathrm{~mm}$ (Fig. 12). Both Arkell (1938) and Enay (1966) considered the holotype to be the inner whorls of a coarsely ribbed, macroconch Perisphinctes s.s. On this interpretation, variocostation sets in rapidly, changing through simple, coarse primary ribs to bold, wedge-shaped ribs over a quarter of a whorl (Fig. 14B). Specimen SM J374 (Figs 13E and 14D) has the extremely wide, cuneiform and even flat topped ribs on the late phragmocone and early body chamber that distinguishes $P$. chloroolithicus from $P$. parandieri (Arkell 1938, p. 98). The ribbing on the mature stage of $P$. parandieri is much more pointed (Fig. 11D) and curves gently forward (Fig. 11B), without a marked wedge shape (Arkell 1939, p. 106). The rib curve of SM J3836 (Fig. 12:16) matches quite closely that of $P$. chloroolithicus as interpreted by Enay (1966). 

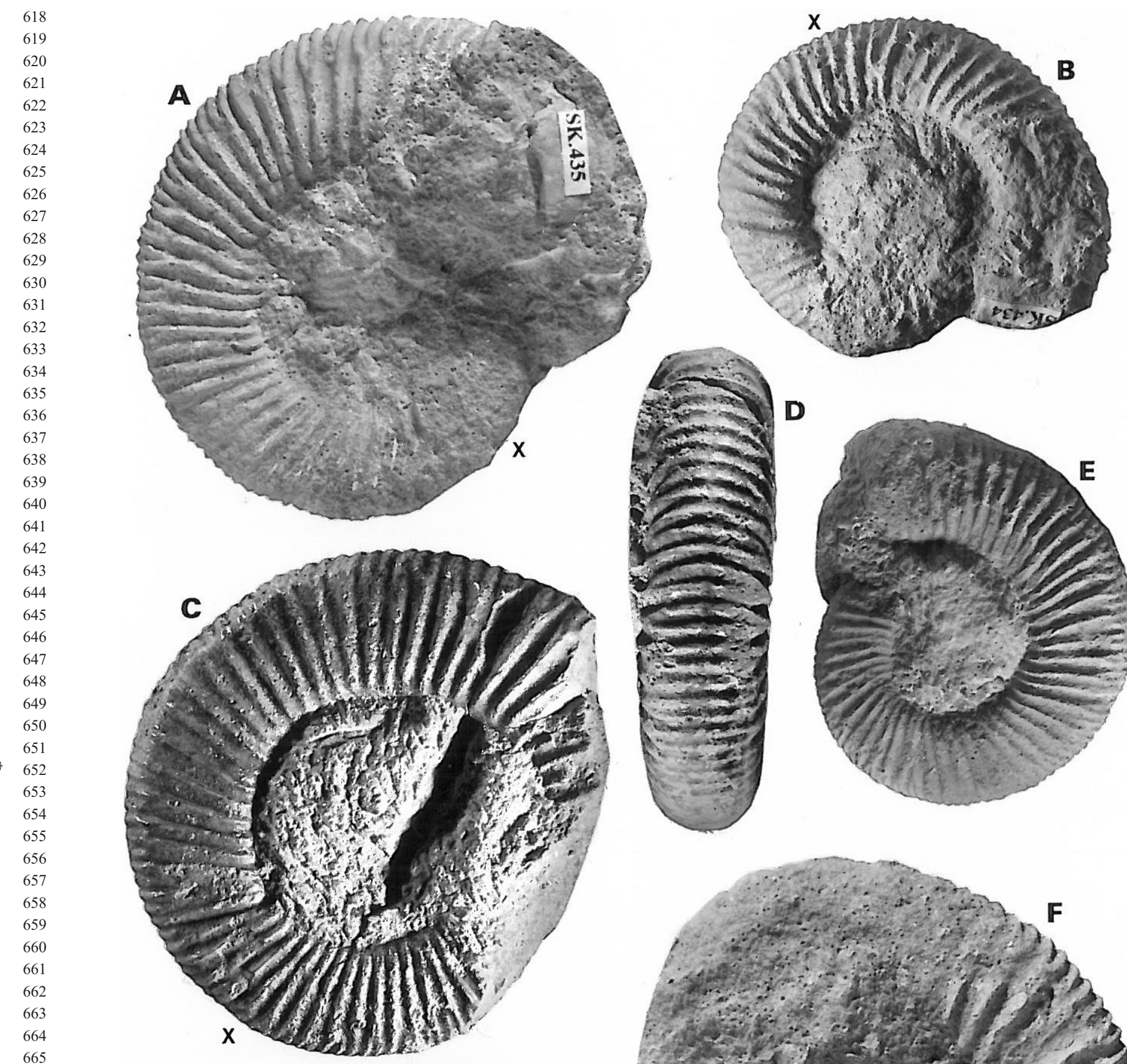
Remarks. The species as interpreted here includes the variants from Upware and Normandy with extremely coarse ribbing on the body-chamber described by Arkell (1938, pp. 96, 97). Specimens from the Headington Shell Bed with less coarse ribbing on the body-chamber, described by Arkell (1938) as P. chloroolithicus, are included here in P. tumulosus.

Perisphinctes (Perisphinctes) holtonensis Buckman (Figs 13A and 14A,C)

1927 Dichotomosphinctes holtonensis sp. nov.; Buckman pl. 715 .

1939 Perisphinctes (Arisphinctes) maximus (Young \& Bird); Arkell, p. 117.

1939 Perisphinctes parandieri de Loriol; Arkell, text-fig. 32.

1966 Perisphinctes (Perisphinctes) andelotensis; Enay, pp. 366-371, pl. 9, figs 1a, b, 2a-c.

1966 Perisphinctes (Perisphinctes) aff. andelotensis; Enay, pp. 366-371, pl. 9, figs 3a, b.

?1995 Perisphinctes (Dichotomosphinctes) dobrogensis Simionescu; Gygi, pp. 34, 36, fig. 15.

Material. Four specimens: SM J363 (North Pit), SM J371 (?North Pit), SM J383 ('Bridge Pit'), SM X.50214 (Bridge Pit South), by matrix from Bed 9.

Measurements. SM X.50214 (Fig. 13A); D (phg-juv) $121 \mathrm{~mm}, \mathrm{D}(\max ) 180 \mathrm{~mm}$; at $160 \mathrm{~mm}, 0.23,0.24(0.22)$, 0.57 ; ribs 50 at $115 \mathrm{~mm}, 51$ at $129 \mathrm{~mm}, c .44$ at $180 \mathrm{~mm}$.

SM J363 (Fig. 14A,C); D (max) $180 \mathrm{~mm}$; at $156 \mathrm{~mm}, 0.21$, $0.28(0.25), 0.61$; ribs 40 at $180 \mathrm{~mm}$.

Description. Buckman's holotype has the inner whorls poorly preserved. The present specimens show that the rib curve rises gently from $50 \mathrm{rpw}$ at $60 \mathrm{~mm}$ to $56-60 \mathrm{rpw}$ at $120 \mathrm{~mm}$ (Fig. 12). The stage of coarse primary ribbing separating the dense ribbing of the inner phragmocone from the coarse, wedge-shaped ribbing of the body-chamber is long, at least half a whorl, giving the rib curve a very gentle inverted $U$ shape (Fig. 12:7 and 14). The downturn of the curve starts at between 120 and $140 \mathrm{~mm}$, much earlier than in other species of Perisphinctes s.s. All the Upware specimens are situated on the graph very close to the line of Buckman's holotype.

Remarks. P. holtonensis is distinguished from $P$. parandieri by the earlier onset of variocostation. Arkell (1939, p. 111) could find nothing to separate $P$. holtonensis from $P$. parandieri, but unfortunately he mis-plotted the rib curve of $P$. holtonensis in his text-figure 108. The rib curve of $P$. holtonensis is much shallower than Arkell thought. Because of this, specimen SM J363, considered by Arkell to belong to Arisphinctes (=Kranaosphinctes), fits quite nicely as the inner whorls of $P$. holtonensis. The rib curve of Enay's $P$. (P.) andelotensis also matches that of the holotype of $P$. holtonensis very closely. The specimen figured as a Dichotomosphinctes by Gygi (1995) has modified ribs suggestive of an immature or incompletely preserved Perisphinctes s.s. Its rib curve matches very closely that of SM X.50214 (Fig. 13A).

Subgenus Kranaosphinctes Buckman 1924

Type species. Kranaosphinctes kranaus Buckman 1921, pl. 243.

Perisphinctes (Kranaosphinctes) ariprepes (Buckman) (figs 4A,C and 5A,E)

1924 Arisphinctes ariprepes sp. nov.; Buckman, p. 33, pl. 511A, B.

1939 Perisphinctes (Arisphinctes) cotovui Simionescu; Arkell, p. 126 (pars), figs 39-43; pl. 24, figs 3, 4, 5a, b; pl. 25, fig. 3 only, non text-figs 41, 42; pl. 25, fig. 1a-f. 2002 Perisphinctes (Kranaosphinctes) ariprepes

(Buckman); Głowniak, pp. 344, 345, pl. 13, fig. 1, text-figs 17, 22 (contains full synonomy).

2006 b Perisphinctes (Kranaosphinctes) ariprepes (Buckman); Głowniak, pp. 191-192.

Material Four specimens from the Dimmock's Cote Marl: a large, complete specimen $415 \mathrm{~mm}$ in diameter (SM X.50139.97) from Bed 1, a smaller specimen, $260 \mathrm{~mm}$ maximum diameter and thus a possible juvenile macroconch (SM X.50139.89) from beds 2 or 3, a nearly complete juvenile macroconch showing the inner whorls from beds 2 or 3 (SM X.50139.35), and a smaller body-chamber fragment (SM X.50139.48) from Bed 3.

Measurements. SM X.50139.35 (Fig. 4A): D (phg-juv) $110 \mathrm{~mm}, \mathrm{D}(\max ) 167 \mathrm{~mm}$; at $147 \mathrm{~mm}, 0.24,-, 0.56$; ribs 26 at $28 \mathrm{~mm}, 37$ at $45 \mathrm{~mm}, 43$ at $80 \mathrm{~mm}, 51$ at $140 \mathrm{~mm}, 53$ at $167 \mathrm{~mm}$.

SM X.50139.97 (Fig. 5A,E): D (max) $415 \mathrm{~mm}$; at $335 \mathrm{~mm}$, $0.23,0.25(0.21), 0.64$; ribs 45 at $110 \mathrm{~mm}, 51$ at $195 \mathrm{~mm}, 53$ at $260 \mathrm{~mm}, 41$ at $300 \mathrm{~mm}, 35$ at $330 \mathrm{~mm}, 31$ at $415 \mathrm{~mm}$.

Description. SM X.50139.97 has half a whorl of mature body-chamber at $415 \mathrm{~mm}$ (Fig. 5A). It is septate to $315 \mathrm{~mm}$, the last quarter of a whorl of body-chamber having broken away, making its maximum original diameter $c .470 \mathrm{~mm}$. The specimen is a typical Kranaosphinctes, showing a gradual development of variocostation from a diameter of around $190 \mathrm{~mm}$, some one and a half whorls before the final mature aperture. The inner whorls are regularly and sharply ribbed and variocostation develops by a gradual increase in the spacing of the primary ribs (Fig. 3). There is an associated decrease in sharpness, the ribs becoming more massive

Fig. 7. P. (Otosphinctes) and P. (Dichotomosphinctes) from Bed 6 of the Upware Limestone of Dimmock's Cote Quarry. All natural size.

(A) Perisphinctes (Dichotomosphinctes) buckmani Arkell [m]; SM X.50139.27. (B) Perisphinctes (Otosphinctes) sp. A [m]; SM X.50139.26. (C, D) Perisphinctes (Dichotomosphinctes) buckmani Arkell [m]; SM X.50139.42. (E) Perisphinctes (Dichotomosphinctes) buckmani Arkell [m]; SM X.50139.71; an almost complete whorl of body-chamber. (F) Perisphinctes (Dichotomosphinctes) antecedens Salfeld [m]; SM X.50139.44; body-chamber present but aperture broken away. (G) Perisphinctes (Dichotomosphinctes) buckmani Arkell [m]; SM X.50139; fragment of body chamber. 


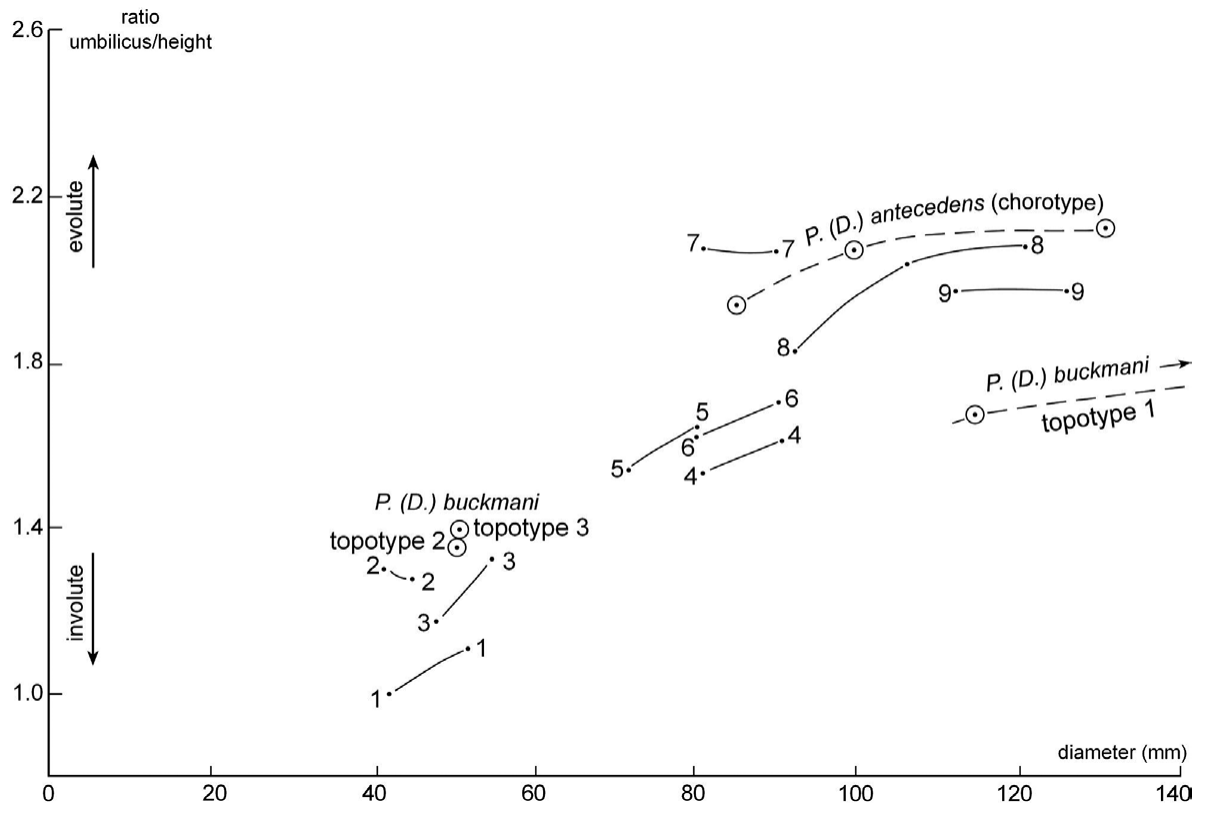

Fig. 8. Plots of umbilicus/whorl heigh ratios for $P$. (Dichotomosphinctes) spp. from Bed 6 of the Upware Limestone of Dimmock's Cote Quarry. 1-5, P. (D.) buckmani Arkell. 6-9, P. (D.) antecedens Salfeld. 1, SM X.50139.47; 2, SM X.50139.53; 3, SM X.50139.71; 4, SM X.50139.42; 5, SM X.50139.27; 6, SM X.50139.44; 7, SM X.50139.88; 8, SM X.50139.87; 9, SM X.50139.29. but not changing their basic shape. Towards the mature aperture, the ribs become slightly closer. Secondary ribs are absent on the final whorl, which has a distinctive flattened venter (Fig. 5E). A single specimen, $167 \mathrm{~mm}$ in diameter (septate to around $115 \mathrm{~mm}$ ), appears to represent an almost complete juvenile macroconch (Fig. 4A). Ribbing is strong, and although dominantly biplicate, some triplicate ribs are present. The apparent forward curve of the ribs on the figured specimen is due to partial crushing of the body chamber. SM X.50139.89 may be a juvenile macroconch, being preserved to around $260 \mathrm{~mm}$ diameter, but septate to $200 \mathrm{~mm}$, with wedge-shaped ribbing beginning at about $230 \mathrm{~mm}$ (Fig. 4C).

Remarks. The macroconchs are typical of a number of large Kranaosphinctes figured (as Arisphinctes) by Arkell (1939), including $P$. (K.) cotovui Simionescu (the holotype of which is now considered to be from the Upper Oxfordian Bimammatum Chronozone; J.H. Callomon, personal communication, 2005) and $P$. (A.) ingens (Young \& Bird). All these forms have relatively close-ribbed body-chambers but, in the absence of good stratigraphical control on the source level of most specimens, discussions on synonymies and correlations are problematic. Głowniak (personal communication, 2007) has noted that the wedge-shaped ribs of SM X.50139.89 are more characteristic of Perisphinctes s.s. than Kranaosphinctes. This specimen thus marks a transition from the former into the latter subgenus. However, its rib curve is closer to that of Kranaosphinctes than Perisphinctes s.s. (Fig. 3:6). The rib curves of the Dimmock's Cote Marl macroconchs thus match quite well those of $P$. ariprepes as figured by Głowniak (2002, fig. 22), but the Upware specimens have bolder ribs and a steeper downturn of the rib curve at larger dimensions, more indicative of Perisphinctes s.s.

\section{Perisphinctes (Kranaosphinctes) aff. maximus (Young \&} Bird) (Figs 4D and 5C,D)

1828 Ammonites maximus sp. nov.; Young \& Bird, 2nd edition, p. 255 (no figure).
1914 Perisphinctes parandieri de Loriol; Salfeld, p. 238, pl. 13, fig. 5.

1924 Arisphinctes maximus Young \& Bird; Buckman, pl. 512 (holotype figured).

1939 Perisphinctes (Arisphinctes) maximus (Young \& Bird); Arkell, pp. 112-118

pl. 19, figs $1-3$, pl. 20, figs $1-4$, pl. 21, fig. 2, pl. 22, figs 1 , 2, pl. 25, fig. 4, text figs 34,35 .

1972 Perisphinctes (Arisphinctes) maximus (Young \& Bird); Malinowska, pp. 182-184, pl. 3.

Material. Two body-chamber fragments (SM X.50139.60, -.61) of a macroconch perisphinctid from the Dimmock's Cote Marl, probably from Bed 4.

Description. These body chamber fragments (Figs 4D and 5C,D) are close to $P$. (K.) ariprepes, but have more widely spaced primary ribs on the body-chamber than occur in $P$. (D.) ariprepes. The fauna of the highest Dimmock's Cote Marl thus includes specimens with this widely spaced rib style and a more rounded mature whorl section.

Remarks. The widely spaced ribbing and rounded whorl section suggest a comparison with $P$. (A.) maximus (Young $\&$ Bird), specifically specimens figured by Arkell (1939, pl. 19, figs 3 and pl. 20, figs 1, 2, 4). With more complete, accurately located material, it may be possible to define a discrete transient species at this level.

Perisphinctes (Kranaosphinctes) sp. aff. decurrens Buckman (Fig. 10E)

1923 Kranaosphinctes decurrens sp. nov.; Buckman, pl. 449.

1939 Perisphinctes (Kranaosphinctes) decurrens Buckman; Arkell, pl. 38, fig. 4; pl. 39, figs 1-6; text-fig. 62.

1963 Perisphinctes (Kranaosphinctes) decurrens Buckman; Malinowska, p. 155, pl. 33, igs 157a, b. 1977 Perisphinctes (Kranaosphinctes) decurrens Buckman; Matyja, pl. 7, fig. 7. 


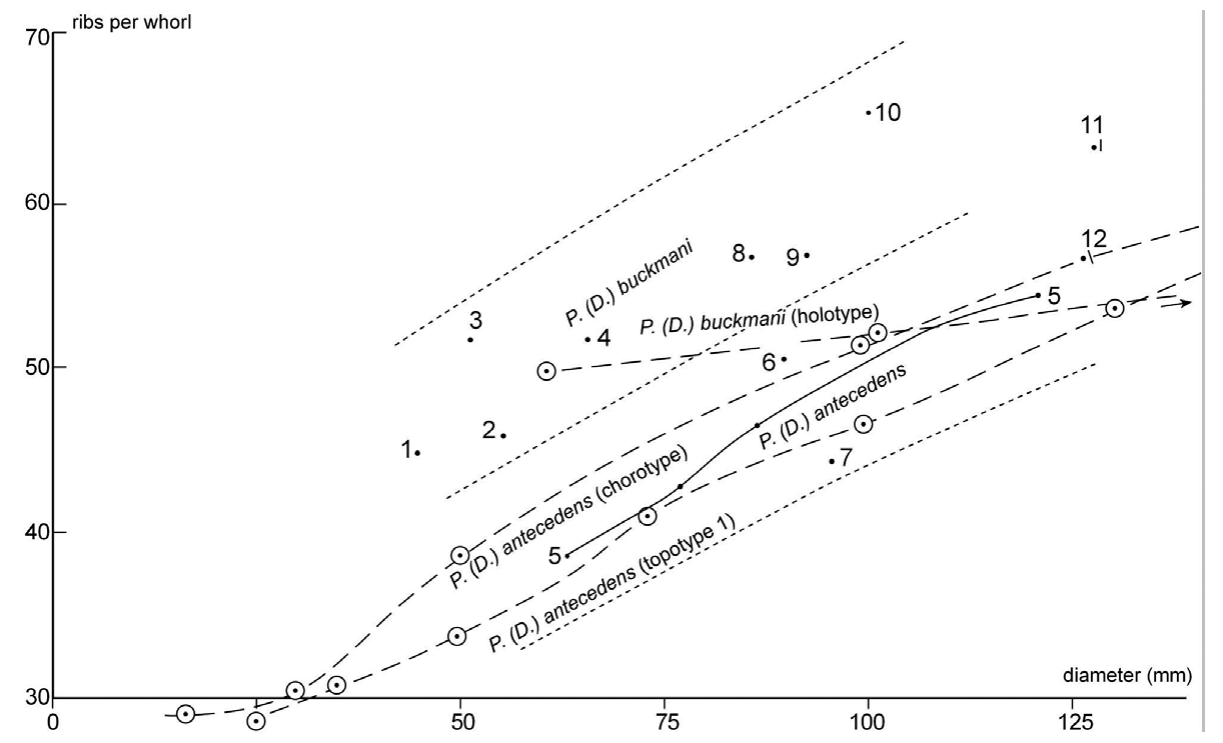

Fig. 9. Rib curves and rib counts for $P$. (Dichotomosphinctes) spp. from Bed 6 of the Upware Limestone of Dimmock's Cote Quarry. 1-4, 8-10, P. (D.) buckmani Arkell. 5-7, 11-12, P. (D.) antecedens Salfeld. 1, SM X.50139.53; 2, SM X.50139.70; 3, SM X.50139.47; 4, SM X.50139.71; 5, SM X.50139.87; 6, SM X.50139.88; 7, SM X.50139.44; 8, SM X.50139.27; 9, SM X.50139.42; 10, SM X.50139.69; 11, SM X.50139.34; 12, SM X.50139.29

Material. One largely complete juvenile specimen (SM X.50139.28) and one body-chamber fragment (SM X.50139.36) from the Upware Limestone, Crinoid Bed (beds 6b-c).

Measurements. SM X.50139.28 (Fig. 10E): D (phg-juv.) $107, \mathrm{D}(\max ) 138 \mathrm{~mm}, 0.6 \mathrm{wh}$ bch; at $91 \mathrm{~mm}, 0.27,0.32$, 0.55 ; ribs 42 at $97 \mathrm{~mm}, c .44$ at $140 \mathrm{~mm}$.

Description. The juvenile specimen (Fig. 10E) is well preserved, showing features characteristic of Kranaosphinctes, with bold primary ribbing, much less prominent bifurcating secondaries, a depressed whorl section and prominent, prorsiradiate constrictions with marked interruption of the ribbing. Constrictions are frequent, three or four per whorl, though not deep. Each is followed by a strong, simple rib whose trend is then followed by that of the primary ribbing. The whorl section is depressed, being $18 \mathrm{~mm}$ high at $70 \mathrm{~mm}$ diameter, with the whorl breadth $23 \mathrm{~mm}$. Sutures are thin and difficult to make out, but the last septum in this specimen appears to be at $107 \mathrm{~mm}$. The maximum preserved diameter of $140 \mathrm{~mm}$ appears to be close to the maximum diameter achieved by this juvenile; the last two ribs, visible on the reverse of the specimen, are both simple, but no aperture is preserved. Specimen SM X.50139.36 (not figured) is a body-chamber fragment from close to the aperture of an individual some $250-300 \mathrm{~mm}$ in diameter. It shows coarse, regularly spaced primary ribs passing strongly over the venter as simple ribs and with biplicate secondaries.

Remarks. SM X.50139.28 is comparable with specimens identified as $P$. (K.) decurrens by Arkell (1939), particularly the specimen illustrated in his plate 39 , figure 4 . This latter specimen has the markedly prorsiradiate primary ribbing that is particularly prominent at $120 \mathrm{~mm}$ in diameter in our specimen. However, Arkell's specimen has predominantly triplicate secondaries at this diameter, whereas almost all secondaries bifurcate in the Upware specimen. Another specimen of $P$. (K.) decurrens (Arkell 1939, pl. 39, figs $6 \mathrm{a}, \mathrm{b})$, though having much more rectiradiate ribbing than SM X.50139.28, does have predominantly biplicate secondaries at $120-130 \mathrm{~mm}$.
It must be admitted that the rib curve of the Upware specimen (Fig. 6:5) does not have the falling off between 100 [A0:3] and $150 \mathrm{~mm}$ that characterizes $P$. decurrens (Arkell 1939, fig. 61) and is more like that of $P$. (K.) kranaus (Buckman). However, none of the specimens of $P$. (K.) kranaus figured by Arkell (1939, pl. 38), though prosiradiate to some extent, have markedly prorsiradiate ribbing.

SM X.50139.36, a whorl fragment of whorl height $62 \mathrm{~mm}$, has coarse secondary ribbing passing strongly over the venter close to the aperture in the manner of $P$. (K.) bullingdonense Arkell. Arkell's species came from the Antecedens Subchronozone, so a close match with the Upware specimens from the lower Parandieri Subchronozone is not to be expected. Głowniak (personal communication, 2007) has noted the similarity of SM X.50139.28 to the inner whorls of some Perisphinctes s.s. from Poland. A further interesting new species of Kranaosphinctes was reported from the Antecedens Subchronozone by Callomon (1960).

Subgenus Otosphinctes Buckman, 1926

Type species. Otosphinctes ouatius Buckman, 1926, pl. 649, figs $1,2$.

Perisphinctes (Otosphinctes) cf. ouatius (Buckman) (Fig. 5B)

1926 Otosphinctes ouatius sp. nov.; Buckman, pl. 649, figs 1,2 .

1938 Perisphinctes (Dichotomosphinctes) ouatius

(S. Buckman); Arkell, pp. 93-94, pl. 17, figs 1, 2, 5, 6, 10. 2002 Perisphinctes (Otosphinctes) ouatius ouatius

(Buckman 1926); Głowniak, pl. 5, fig. 3; pl. 6, figs 2-3; p. 9, figs 1-2; text-figs $5,12,14$ (includes detailed synonomy).

Material. Two specimens (SM X.50139.57, -.63) from beds 2-4 of the Dimmock's Cote Marl.

Measurements. SM X.50139.63 (Fig. 5B): D (max) $36.5 \mathrm{~mm}$; at $34 \mathrm{~mm}$ : 0.29, 0.37 (0.32), 0.47; 33 ribs.

Description. The specimens consist of internal moulds of parts of the inner whorls, well preserved in calcareous 
K. N. Page et al.

894

895

897

898

899

900

90

903

907

909

912

914

915

918

919

922

923

926

(๑) $\quad 927$

929

930

931

933

934

936

937

938

939

940

941

942

943

944

94

946

94

948

949

950

952

954

955

956

957

958

959

960

961

962

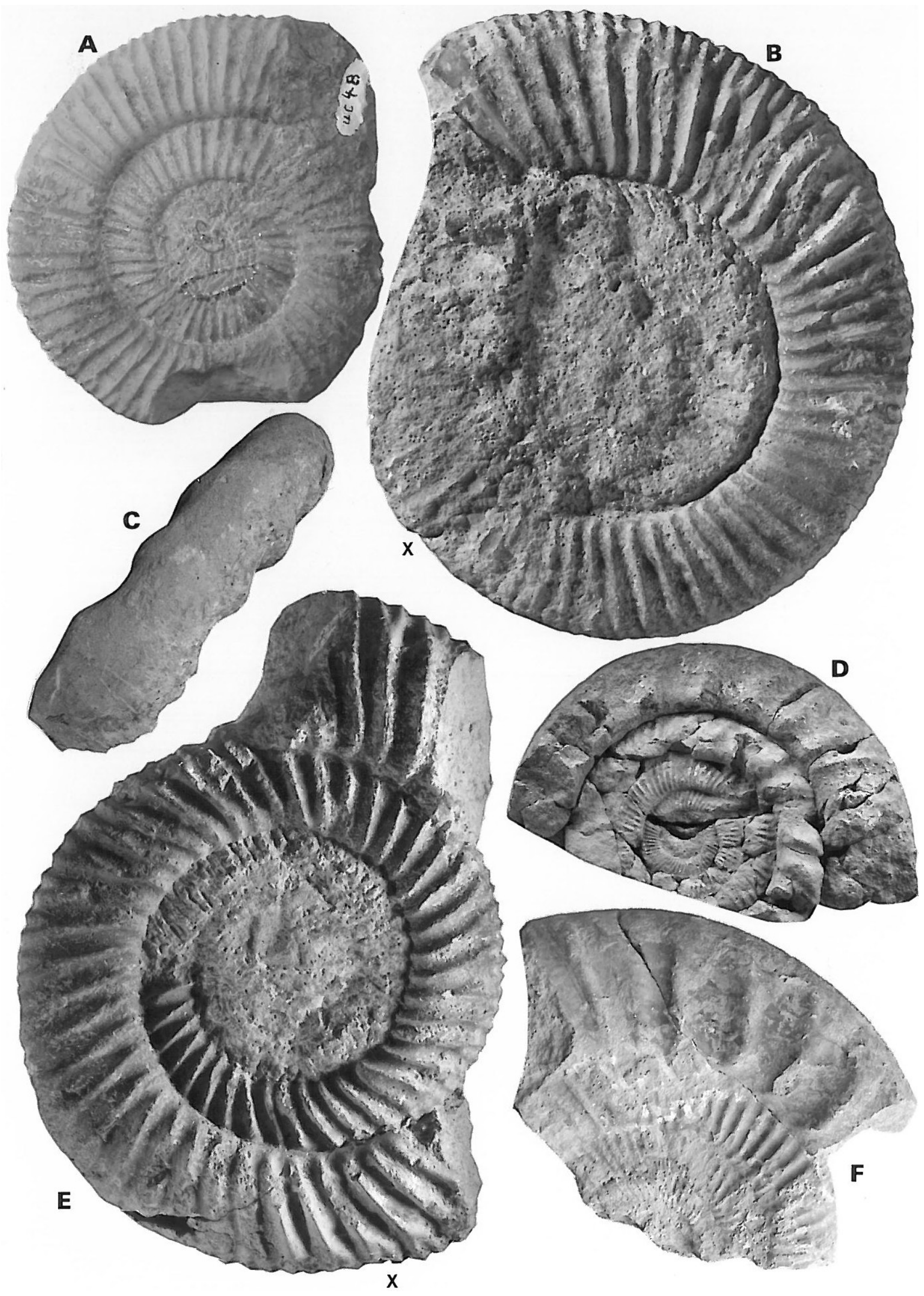

$\oplus$ 
concretions, but not showing sutures. The primary ribs are sharp, initially trifurcating, then bifurcating regularly after $25 \mathrm{~mm}$ diameter. The secondaries pass strongly over the venter with a slight forward sweep. A deep constriction is present in SM X.50139.63, followed by an oblique simple rib. The whorl section of this specimen is circular; that of the other specimen is slightly depressed, subquadrate.

Remarks. The presence of the deep constriction distinguishes the present species from $P$. (O.) ouatius ouatoides Głowniak. The circular to depressed whorl section distinguishes $P$. (O.) ouatius ouatius from $P$. (O.) arkelli arkelli Głowniak, the latter having an oval whorl section. However, there is considerable variation in the whorl section of Plicatilis Chronozone Otosphinctes (Głowniak 2002) and, in order to be certain of identifications, it is necessary to have adult specimens complete with aperture, something not present in any of the Upware Otosphinctes.

\section{Perisphinctes (Otosphinctes) cf. arkelli Głowniak} (Fig. 4B)

1938 Perisphinctes (Dichotomosphinctes) rotoides Ronchadze; Arkell, pp. 90-93, pl. 16, figs 1-5, 7. 2000 Perisphinctes (Otosphinctes) arkelli sp. nov.; Głowniak, p. 153 (pars), text-fig. 10, pl. 5, figs 1-3. 2002 Perisphinctes (Otosphinctes) arkelli arkelli chronosubsp. nov.; Głowniak, p. 332, pl. 14, figs 2-3, text fig. 16.

Material. Four specimens (SM X.50139.25, -.37, -.50, -.76) from beds 2-4 of the Dimmock's Cote Marl.

Measurements. SM X.50139.76 (not figured): D (max) $37 \mathrm{~mm}$; at $37 \mathrm{~mm}: 0.32,0.27,0.41 ;$ c. 35 ribs.

Description. The figured specimen (SM X.50139.50) is largely complete with body-chamber, the inner septate whorls being crushed; the specimen is thus probably immature. The ribbing is fine, moderately dense, bifurcating regularly, and passing strongly over the venter. The whorl section is oval. An oblique simple rib is present, with no noticeable constriction.

Remarks. This species is distinguished from $P$. (O.) ouatius by the absence of constrictions, combined with the slightly compressed, oval whorl section. It is distinguished from $P$. (O.) arkelli wysoka Glowniak by the presence of the oblique simple rib. Głowniak (2000) has pointed out that Arkell (1938) incorrectly allocated these microconchs to $P$. (D.) rotoides Ronchadze, now regarded as a Transversarium Chronozone Dichotomoceras. One specimen figured by Arkell (1938, pl. 16, fig. 6) as $P$. rotoides is $100 \mathrm{~mm}+$ in diameter. It was allocated to $P$. (O.) arkelli arkelli by
Głowniak (2002). However, we consider that such specimens should be allocated to $P$. (O.) arkelli wysokae, and that $P$. (O.) arkelli arkelli should be used for specimens of 80-95 mm maximum diameter. Głowniak (personal communication, 2007) has noted that the presence of parabolic nodes in this specimen means that it is quite close to P. ouatius.

Perisphinctes (Otosphinctes) sp. A (Fig. 7B)

?1977 Perisphinctes (Otosphinctes) sp. A. Matyja, pl. 8, fig. 7.

Material. Three fragmentary microconchs (SM X.50139.26, $-.73,-.84)$ from the Upware Limestone, Sponge Bed (Bed 6a).

Measurements. SM X.50139.26 (Fig. 7B): D (max) $66 \mathrm{~mm}$, sutures indistinct; $0.3 \mathrm{wh} \mathrm{bch}$; at $59 \mathrm{~mm} ; 0.28,0.35,0.50$; ribs $c .48$

SM X.50139.73 (not figured): D (max) $42 \mathrm{~mm}$, entirely septate. At $35 \mathrm{~mm}, 0.33,0.36,0.46$; ribs 18 per half whorl at $42 \mathrm{~mm}$.

Description. This is an evolute form, moderately densely ribbed in the early whorls, but becoming quite densely ribbed later. The primary ribs are strong, noticeably prorsiradiate, and bifurcate regularly into secondaries. The secondaries do not carry on the prorsiradiate trend, but cross the venter in a much more rectiradiate manner. The figured specimen, SM X.50139.26 (Fig. 7B), shows a marked, strongly prorsiradiate constriction.

Remarks. These very distinctive specimens, with their markedly depressed whorl section and prorsiradiate ribbing, appear to match very few species figured by previous workers. The best match is with P. (O.) sp. A of Matyja (1977), which has similar bold, prorsiradiate primary ribbing, but is slightly more evolute.

Subgenus Dichotomosphinctes Buckman 1926

Type species. Perisphinctes antecedens Salfeld 1914, designated by Buckman 1926, pl. 650.

Perisphinctes (Dichotomosphinctes) antecedens Salfeld (Figs $7 \mathrm{~F}$ and 10A,B)

1914 Perisphinctes $\mathrm{cf}$. Wartae Bukowski, mutatio antecedens Salfeld, p. 239, pl. 12, fig. 3.

non 1926 Dichotomosphinctes antecedens Buckman, pl. 650 (P. buckmani Arkell).

1936 a Perisphinctes (Dichotomosphinctes) antecedens Salfeld; Arkell, p. xlv, Pl. D.

1938 Perisphinctes (Dichotomosphinctes) antecedens Salfeld; Arkell, pp. 83-90, pl. 14, fig. 6; pl. 15, figs 1-6; pl. 16 , fig. 8 . 
K. N. Page et al.

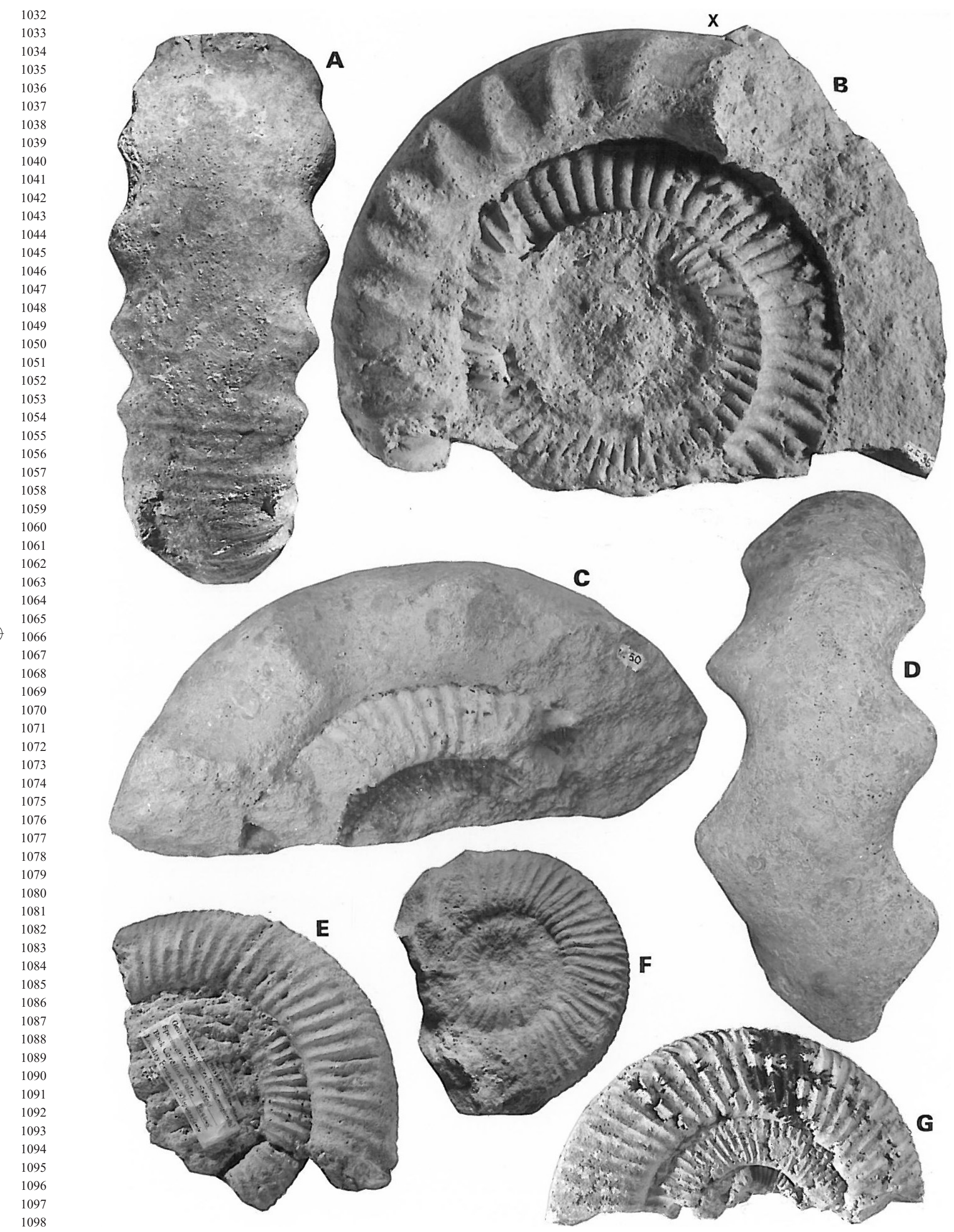

$\oplus$ 


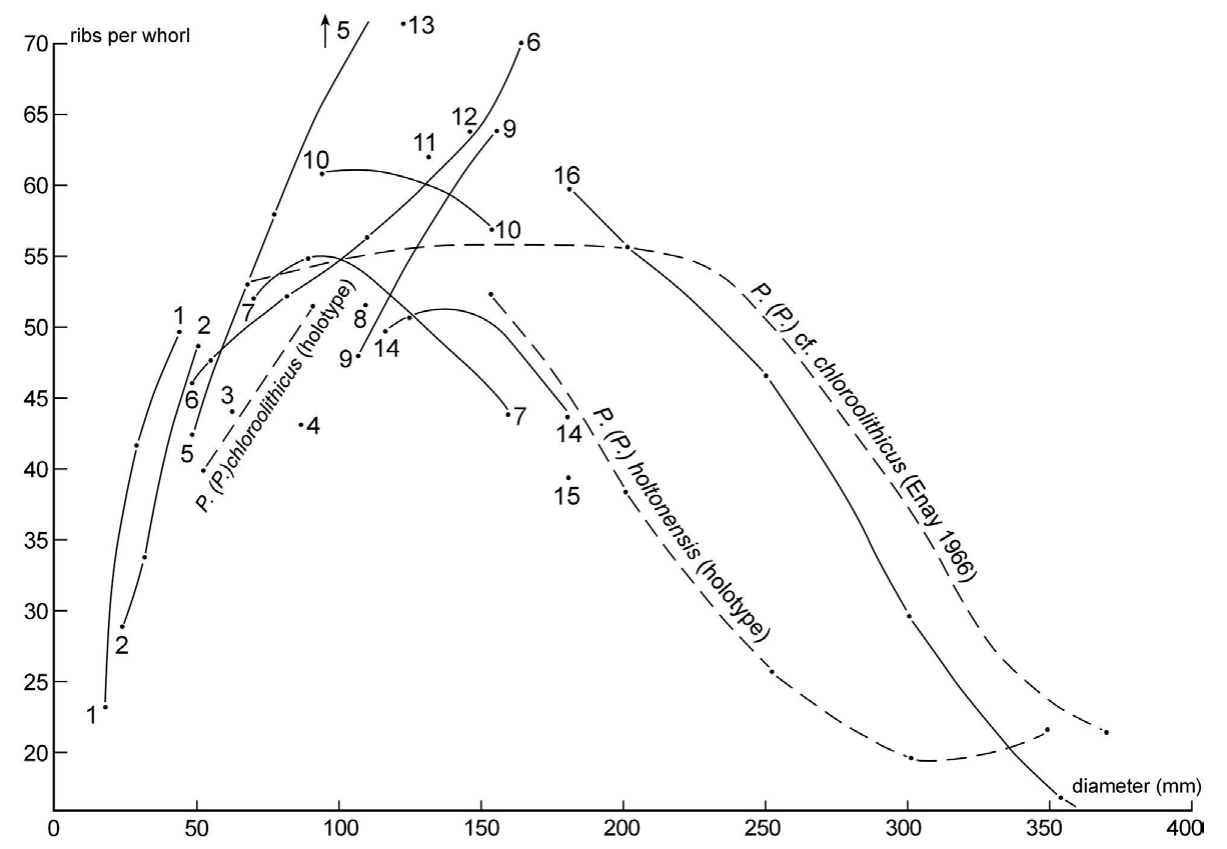

Fig. 12. Rib curves of perisphinctids from the Upware Limestone, Bed 9. 1-6, 9, 11, 12-13, Perisphinctes (Dichotomosphinctes) aff. dobrogensis Simionescu; 7-8, 14-15, P. (P.) holtonensis Buckman; 10, 16, P. (P.) chloroolithicus Gümbel. 1, SM J382 ('New Pit'); 2, SM J53029 (Padney); 3, SM J349 (South Pit); 4, SM J18240 ('Bridge Pit'); 5, SM X.50139.40 (Dimmock's Cote Quarry); 6, SM J20256 (Bridge Pit North); 7, SM J371 (?North Pit); 8, SM J383 ('Bridge Pit'); 9, SM J48645 (Bridge Pit North); 10, SM J359 (North Pit); 11, SM J380 ('Bridge Pit'); 12, SM X.50139.39 (Dimmock's Cote Quarry); 13, BMNH C89588 (Bridge Pit North); 14, SM X.50214 (Bridge Pit South); 15, SM J363 (North Pit); 16, SM J3836 ('New Pit').

2006 b Perisphinctes (Dichotomosphinctes) antecedens Salfeld; Głowniak, pp. 186-189, fig. 12.

2007 Perisphinctes (Dichotomosphinctes) cf. antecedens Salfeld; Głowniak \& Wierzbowski, pp. 77-79, figs 40/1-2.

Material. Six specimens from the Upware Limestone, Crinoid Bed (beds 6b-c): SM X.50139.29, -.34, -.43, -.44, $-.87,-.88$.

Measurements. SM X.50139.29 (Fig. 10B): D (max-ad) $123 \mathrm{~mm}$; at $100 \mathrm{~mm}, 0.27,0.26,0.57$; ribs $c .55$ at $125 \mathrm{~mm}$.

SM X.50139.44 (Fig. 7F): D (phg-?juv) $60 \mathrm{~mm}$, D (max) $95 \mathrm{~mm} ; 0.75 \mathrm{wh}$ bch; at $91 \mathrm{~mm}, 0.28,0.25,0.47$; ribs $c .45$ at $79 \mathrm{~mm} ; 47$ at $93 \mathrm{~mm}$.

SM X.50139.88 (not figured): D (max) $122 \mathrm{~mm} . \mathrm{D}$ (phg-ad) $105 \mathrm{~mm} ; 0.25 \mathrm{wh}$ bch; at $122 \mathrm{~mm}, 0.26,0.23,0.53$; at $92 \mathrm{~mm}$, $0.29,0.26,0.53$; ribs 42 at $79 \mathrm{~mm}, 45-46$ at $92 \mathrm{~mm}, 54$ at $122 \mathrm{~mm}$.

Description. The specimens are sharply ribbed to the end, with predominantly bifurcate ribs with some intercalatories. The furcation point is at $75 \%$ to $80 \%$ of the whorl height. Some specimens show secondaries with a slight forward curve. Constrictions are occasionally present. The mature size is around $125-140 \mathrm{~mm}$ with the rib count increasing from $43 \mathrm{rpw}$ at $65 \mathrm{~mm}$ to 55 at $125 \mathrm{~mm}$ (Fig. 6:6-7 and 9). Although no lappet is preserved, one specimen (SM X.50139.29, Fig. 10B) shows some simplification of ribbing close to the mature aperture. The whorl section is typically rectangular with flattened sides, and the venter is broadly rounded. All specimens are characteristically evolute (Fig. 8:1-5), and are less densely ribbed than P. buckmani (Fig. 9).

Discussion. The holotype, refigured by Arkell (1936a, pl. D, fig. 3), is more evolute, with slightly higher bifurcation points and more markedly rectiradiate ribbing than is present in most specimens of $P$. (D.) antecedens as usually interpreted (Arkell 1938, pl. 15, figs 1-6). The Upware specimens match the range of Arkell's specimens almost exactly. Specimen SM X.50139.29 (Fig. 10B) also resembles $P$. (D.) auriculatus Arkell, although the type of that species is slightly larger $(150 \mathrm{~mm}) . P$. auriculatus is from Bed 6 at the Lamb and Flag Quarry, Kingston Bagpuize, near Oxford (Callomon 1960; Arkell 1938, 1948). Bed 6 at the Lamb and Flag Quarry is also the type horizon of the macroconch $P$. (K.) kingstonensis Arkell which, although having comparable inner whorls to those of the fauna of Bed 6 at Dimmock's Cote Quarry (e.g. Arkell 1939, pl. 32, fig. 8, pl. 33, fig. 3), includes quite a different mature morphology, being relatively closely ribbed to the end (Arkell 1939, pl. 32, fig. 7). This morphology may therefore suggest a lower stratigraphic level for $P$. (D.) auriculatus s.s. The specimen of $P$. antecedens figured by Głowniak \& Wierzbowski (2007, fig. 40/1) is very close to one of those figured here (Fig. 10A).

Fig. 11. Perisphinctes s.s. and Dichotomosphinctes from the Upware Limestone. (A, B) Perisphinctes (P.) parandieri de Loriol [M]; SM X.50139.92; top of Bed 6b, Dimmock's Cote Quarry; inner whorls preserved as a mould, end of phragmocone and first quarter of body-chamber well preserved, ventral view of this part of the whorl in B; $\times 0.5$. (C, D) Perisphinctes (P.) parandieri de Loriol; Bed 6, Dimmock's Cote Quarry; SM X.50139.95; x0.39. (E) Perisphinctes (Dichotomosphinctes) aff. dobrogensis Simionescu [m]; SM J48645; matrix of Bed 9, Bridge Pit North; specimen includes at least a third of a whorl of body-chamber and modified ribs close to the aperture; $\times 0.5$. (F) Perisphinctes (D.) aff. dobrogensis Simionescu [?m]; SM J53029; matrix of Bed 9, 'The Dolveis, Padney'; no suture visible; natural size. (G) Perisphinctes (P.) chloroolithicus (Gümbel) [M]; SM J359; matrix of Bed 9, North Pit; completely septate inner whorls; $\times 0.45$; partially figured (as $P$. (D.) buckmani) by Arkell (1938, pl. 14, fig. 2). 
K. N. Page et al.

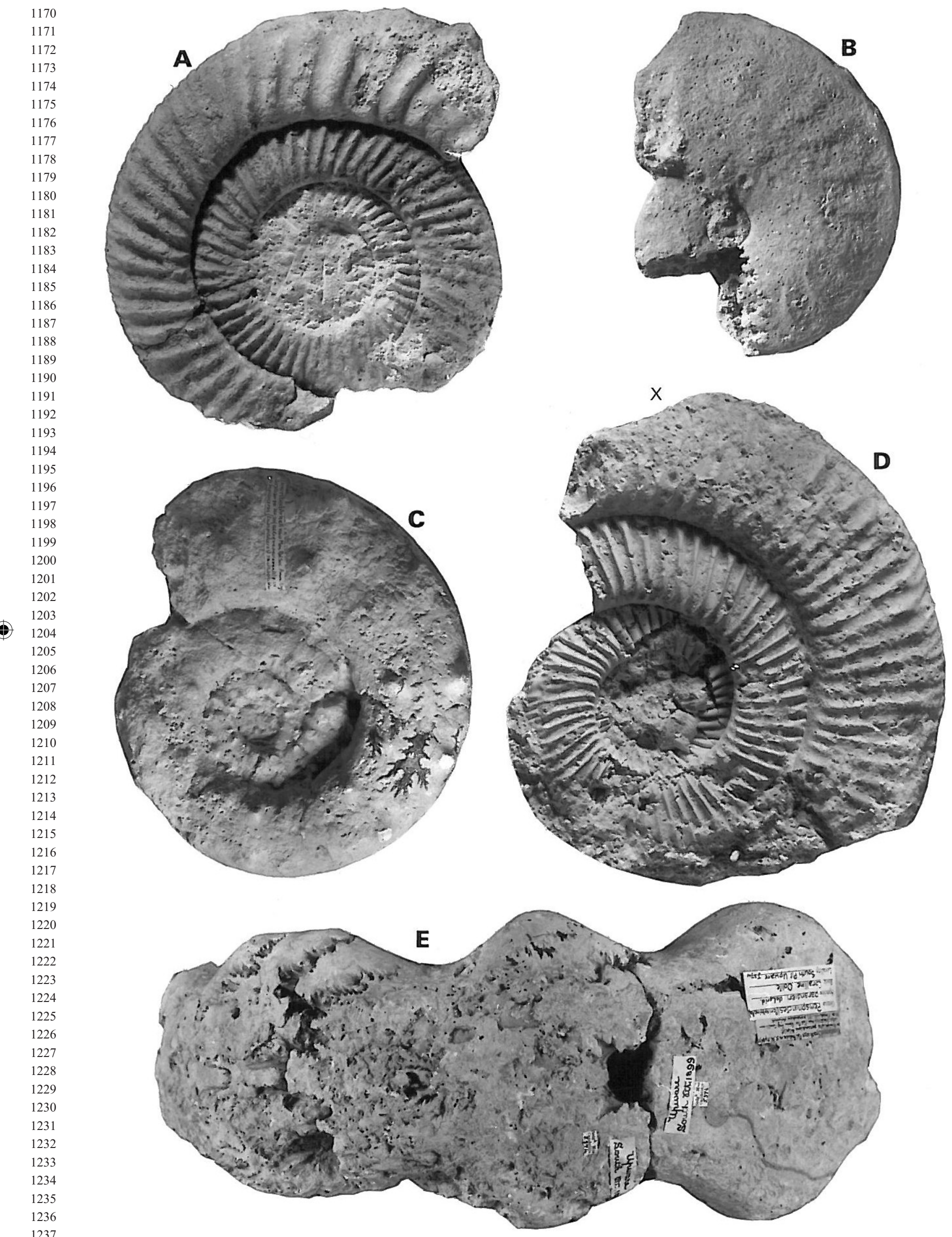


Perisphinctes (Dichotomosphinctes) buckmani Arkell (Fig. 7A, C-E, G)

?1938 Perisphinctes (Dichotomosphinctes) buckmani $\mathrm{sp.}$ nov. Arkell, p. 79, pl. 14, figs 1a, b, 3a, b; pl. 17, figs

$13 \mathrm{a}-\mathrm{c}$.

1963 Perisphinctes (Dichotomosphinctes) dybowskii Siemiradzki; Malinowska, pp. 66, 153, pl. 32, fig. 154, pl. 33, fig. 160 .

1966 Perisphinctes (Dichotomosphinctes) buckmani

Arkell; Enay, p. 478, pl. 28, fig. 5, pl. 29, figs 1, 2.

1972 Perisphinctes (Dichotomosphinctes) buckmani

Arkell; Malinowska, pp. 186, 187, pl. 5.

?1977 Perisphinctes (Dichotomosphinctes) dybowskii Siemiradzki; Matyja, pl. 8, fig. 8.

1990 Perisphinctes (Dichotomosphinctes) antecedens Salfeld; Gygi, p. 183, pl. 5, fig. 4.

2006 berisphinctes (Dichotomosphinctes) buckmani Arkell; Głowniak, pp. 189-190, fig. 13.

2007 Perisphinctes (Dichotomosphictes) cf. buckmani Arkell; Głowniak \& Wierzbowski, pp. 79-82, figs 42/1-3.

Material. Eight specimens (SM X.50139.27, -.41, -.42, -.47, $-.53,-.69,-.70,-.71)$ from the Upware Limestone, Crinoid Bed, (beds 6b-c), Dimmock's Cote Quarry.

Measurements. SM X.50139.27 (Fig. 7A): D (phg-?ad) $57 \mathrm{~mm}$, D (max) $84 \mathrm{~mm} ; 0.66 \mathrm{wh}$ bch; at $82 \mathrm{~mm}, 0.29,0.26$, 0.46 ; ribs c. 55 at $85 \mathrm{~mm}$.

SM X.50139.42 (Fig. 7C,D): D (phg-?ad) $66 \mathrm{~mm}, \mathrm{D}$ (max) $95 \mathrm{~mm} ; 0.66 \mathrm{wh}$ bch; at $89 \mathrm{~mm}, 0.28,0.30,0.49$, ribs c. 59 at $90 \mathrm{~mm}$.

Description. The primary ribbing is fine, almost always bifurcating on the phragmocone, but with occasional simple ribs. The rib density increases from $40-50$ at $50 \mathrm{~mm}$ to 60 at $100 \mathrm{~mm}$ (Fig. 6). Numerous simple ribs are present on the later body chamber. Constrictions are well seen in Figure 7C (SM X.50139.42) and faint in Figure 7E (SM X.50139.71), one per whorl. Coiling is quite involute for a Dichotomosphinctes, the ratio of umbilicus to whorl height varying from 1 to 1.4 at $50 \mathrm{~mm}$, increasing to 1.8 at $80 \mathrm{~mm}$ (Fig. 8). The whorl section is sub-quadrate, slightly convergent.

Remarks. The holotype of P. buckmani (Arkell, 1938, pl. 14, figs $1 \mathrm{a}, \mathrm{b})$ is a specimen of great size for a microconch $(215 \mathrm{~mm})$ with a nearly complete whorl of body-chamber and with little uncoiling or approximation of the ribbing close to the aperture. This suggests that it is more likely to be a juvenile macroconch rather than a microconch. The rib curve rises only gently (Fig. 9), much more typical of the inner whorls of a macroconch. However, additional specimens figured by Arkell (1938, pl. 14, fig. 3, pl. 17, figs 13a-c) are probable medium-sized microconchs and the species has been interpreted by continental authors as such; this approach is followed here. Specimens of $P$. (D.) cf. buckmani figured by Głowniak \& Wierzbowski (2007) are septate to a maximum of $90 \mathrm{~mm}$, with maximum sizes of $120-130 \mathrm{~mm}$, though probably still immature. Specimens figured by Głowniak (2006b) and Malinowska (1972) both have maximum diameters just over $160 \mathrm{~mm}$, and this seems to be a preferred maximum diameter for the species. The specimen figured by Gygi (1990) is over $200 \mathrm{~mm}$ in diameter, and again probably an immature macroconch.

In the Crinoid Bed fauna, $P$. (D.) buckmani appears to be distinguished from $P$. (D.) antecedens by its distinctly smaller size (D-phg averaging $61 \mathrm{~mm}$ compared with D-phg $106 \mathrm{~mm}$ for $D$. antecedens from the same bed). However, this is clearly a preservational factor (see discussion on preservation in Section 1), one specimen of P. (D.) buckmani being $100 \mathrm{~mm}+$ in diameter (Fig. 7G). P. (D.) buckmani is more flat-sided and involute than $P$. (D.) antecedens, as shown in the plot of umbilicus/height ratio (Fig. 8). However, the specimen of $P$. (D.) antecedens shown in Figure 7F (SM X.50139.44), as plotted in Figure 8 (6), is intermediate in this respect, being involute in the inner whorls, but becoming round-whorled and coarsely ribbed on the outer body chamber. It clearly plots in the antecedens field in Figure 9 (7). The main distinguishing features are thus that, firstly, $P$. (D.) antecedens is round-whorled and does not have the flat, convergent sides of $P$. (D.) buckmani. Secondly, $P$. (D.) antecedens is less densely ribbed than $P$. (D.) buckmani; at $80 \mathrm{~mm}$, the former has about $45 \mathrm{rpw}$, whereas most specimens of the latter have 55-60 rpw. This feature is quite clear in the rib density plot (Fig. 9). P. (O.) arkelli wysokae is similarly less densely ribbed, and more evolute, with less convergent sides. $P$. (D.) buckmani (figured as $P$. (D.) dybowskii Siemiradzski) occurs in Poland along with $P$. (O.) sp. A in the 'Grey Limestone', close to the Plicatilis-Transversarium chronozonal boundary (Matyja 1977). Three specimens, regarded as immature microconchs, were figured by Głowniak \& Wierzbowski (2007). These specimens match those figured here very closely, particularly in density of ribbing and degree of involution.

\section{Perisphinctes (Dichotomosphinctes) aff. dobrogensis Simionescu (Figs 11E,F and 13D)}

1907 Perisphinctes dobrogensis sp. nov.; Simionescu, p. 157, pl. 3, fig. 2, (lectotype), pl. 5, fig. 4.

1938 Perisphinctes (Dichotomosphinctes) buckmani Arkell, p. 80, fig. 19.

1966 Perisphinctes (Dichotomosphinctes) dobrogensis Simionescu; Enay, p. 481, pl. 29, figs 3-5, text figs 140, 145.

1995 Perisphinctes (Dichotomosphinctes) dobrogensis Simionescu; Gygi, pp. 34, 36, fig. 14 only. 


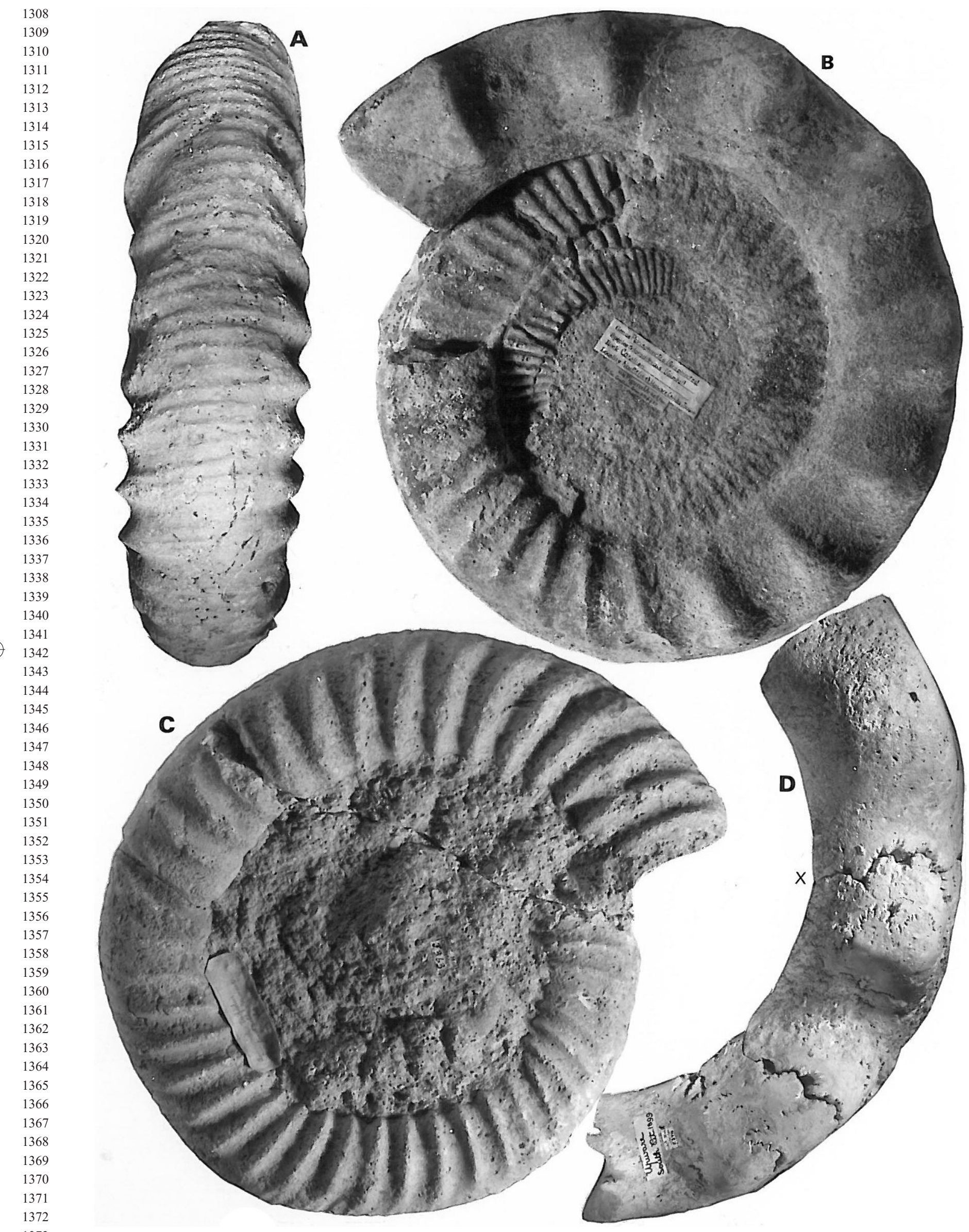


1995 Dichotomosphinctes cf. dobrogensis (Simionescu); Beznosov \& Mitta, pp. 46, 47, pl. 9, fig. 2.

2007 Perisphinctes (Dichotomosphinctes) cf. dobrogensis Simionescu; Głowniak \& Wierzbowski, p. 82, figs $43 / 1,43 / 2$

Material. Seven specimens (SM J349, 'South Pit'; SM J382, 'New Pit'; SM J18240, 'Bridge Pit'; SM J20256 and SM J48645, Bridge Pit North; SM J53029, Padney; SM X.50139.40, Dimmock's Cote Quarry), by matrix from Upware Limestone Bed 9.

Measurements. SM J382 (not figured): ribs c. 23 at $21 \mathrm{~mm}$, c. 42 at $29 \mathrm{~mm}$, c. 50 at $45 \mathrm{~mm}$ (septate inner whorls).

SM X.50139.40 (Fig. 13D): D ( $\max ) 115 \mathrm{~mm}, \mathrm{D}$ (phg-?ad) $110 \mathrm{~mm}$; at $70 \mathrm{~mm}, 0.29,0.23,0.50$; ribs 42 at $45 \mathrm{~mm}, 53$ at $67 \mathrm{~mm}$, c. 58 at $75 \mathrm{~mm}, c .75$ at $105 \mathrm{~mm}$.

SM J48645 (Fig. 11E): D (max) $155 \mathrm{~mm}$; $0.3 \mathrm{wh}$ bch; ribs $c$. 48 at $105 \mathrm{~mm}, c .64$ at $155 \mathrm{~mm}$.

Description. These microconchs appear to mature at around $165 \mathrm{~mm}$ with between 65 and 80 ribs on the last whorl of phragmocone (Fig. 12). The ribs modify near the aperture, passing strongly over the venter, but no lappet is preserved (Fig. 11F). Constrictions are only occasionally present. The specimens are very evolute, with bifurcation points visible beneath the umbilical seam of the overlapping whorl (Fig. 13D).

Remarks. The microconchs from Bed 9 closely resemble $P$. (P.) dobrogensis Simionescu sensu Enay (1966, e.g. pl. 29, figs 3-5). Similar forms have been frequently referred to $P$. (D.) buckmani Arkell (e.g. Arkell 1938, pl. 14, fig. 2, pl. 17, fig. 3; Enay 1966, pl. 29, fig. 1), but P. buckmani is interpreted here as an earlier, more involute microconch. Some doubt exists as to the correct horizon of Simionescu's (1907, p. 157, pl. iii, fig. 2) original Romanian type which could indeed be a homeomorphic Upper Oxfordian form (G. Meléndez, personal communication, 1997). The interpretation of $P$. (D.) dobrogensis here follows Enay (1966) and is consistent with Polish interpretations of the same species (e.g. Matyja \& Głowniak 1994; and E. Głowniak personal communication, 1997). The dense ribbing of the outer whorl of specimen SM X.50139.40 (Fig. 13D) matches $P$. (D.) elizabethae de Riaz (Enay 1966), but $P$. (D.) aff. dobrogensis is more evolute and less densely ribbed on the inner whorls. In this respect, the Upware specimens are slightly less densely ribbed in the inner whorls than those of $P$. (D.) dobrogensis figured by Głowniak \& Wierzbowski (2007); these latter specimens are slightly more involute, not showing bifurcation points in the umbilicus.

$P$. aff. dobrogensis is readily distinguishable from $P$. antecedens by its typically finer ribbing with greater forward sweep of the secondary ribs over the venter and generally more compressed whorl section. More evolute coiling, with bifurcation points visible beneath the umbilical seam, seems to be a variant present in both $P$. antecedens (Głowiak \& Wierzbowski 2007, fig. 40/1), and in $P$. aff. dobrogensis (SM X.50139.40, Fig. 13D).

\author{
Family Aspidoceratidae Zittel 1895 \\ Subfamily Aspidoceratinae Zittel 1895 \\ Genus Aspidoceras Zittel 1868 \\ Subgenus Euaspidoceras Spath 1931
}

Ammonites perarmatus J. Sowerby, 1822; designated by Spath (1931, p. 326, footnote and pp. 588ff.).

Aspidoceras (Euaspidoceras) sp. aff. paucituberculatum Arkell (Fig. 13C)

1892 Ammonites perarmatus J. Sowerby; Roberts, p. 56. 1937b Aspidoceras (Euaspidoceras) paucituberculatum Arkell; Arkell, p. 454

1940 Aspidoceras (Euaspidoceras) paucituberculatum Arkell; Arkell, pp. 210-215, pl. 45, figs 2-5, pls 46, 47, fig. 74.

Material. Two specimens, comprising wholly septate inner whorls (SM J4732) from 'North Pit' and a giant and incomplete outer whorl (not collected) from Dimmock's Cote Quarry. Matrix indicates Bed 9 in both cases (Upware Limestone).

Description. Giant macroconch forms around $450 \mathrm{~mm}$ diameter when complete and septate to around $316 \mathrm{~mm}$. Nucleii are relatively closely ribbed to around $60 \mathrm{~mm}$ diameter with paired umbilical and ventrolateral tubercles. Subsequent ornament develops as widely spaced round tubercles, which persist to the end of septation. Ornament on the body-chamber is much reduced and nodes not developed. Microconch not known.

Discussion. This is the first record of Aspidoceras from the Parandieri Subzone. The specimens from Upware most closely resemble $A$. (E.) paucituberculatum Arkell, the holotype of which (Arkell 1940, pl. 45, fig. 2) is from Bed 6 of the Highworth Limestone at Hangman's Elm Quarry, Highworth, Wiltshire. The fauna of that level predates $P$. (Dichotomosphinctes) antecedens, P. (P.) maximus, Cardioceras (Maltoniceras) maltonense and C. (M.) highworthense in Bed 8 at Highworth, the equivalent of the Crinoid Bed fauna, and therefore suggests that the type of $A$. (E.) paucituberculatum is older than the new specimens from Upware. The ornament of $A$. (E.) perarmatum differs from that of the Upware specimens in that its paired nodes are linked by blunt ribs on the middle whorls. 


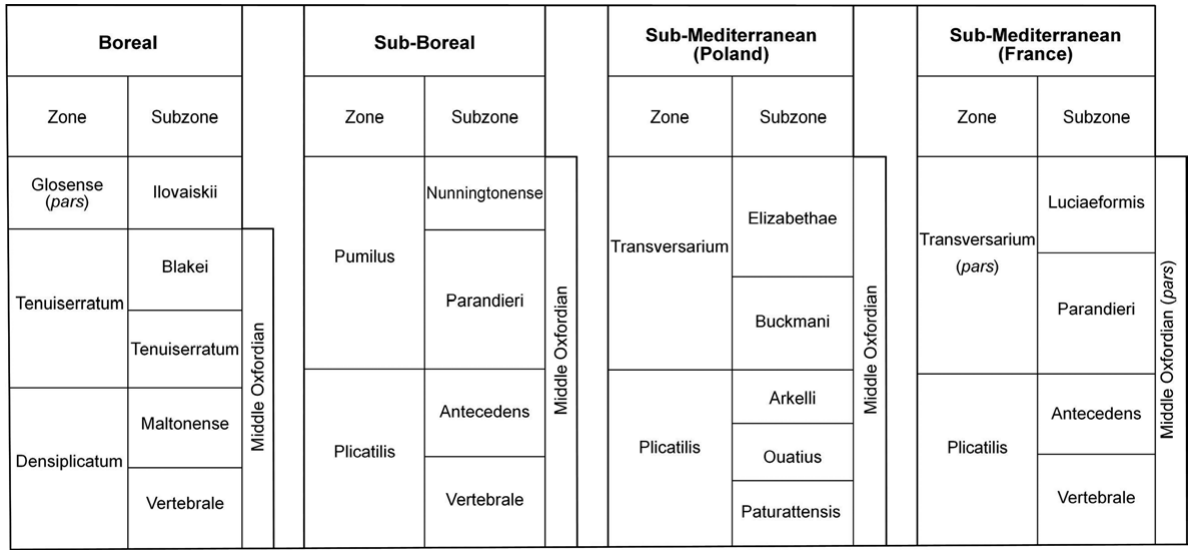

Fig. 15. Correlation of zones and subzones for the Middle Oxfordian of Britain (Boreal and Sub-Boreal), Poland (Sub-Mediterranean) and France (SubMediterranean), after Sykes \& Callomon (1979), Głowniak (2006a) and Cariou et al. (1997). Zones and subzones are used in the sense of Chronozones and Subchronozones, after Callomon (2003). The Middle-Upper Oxfordian boundary is taken higher on the continent than in the UK; above the Transversarium Zone in Poland and higher, above the overlying Bifurcatus Zone, in France.

\section{The correlation of the ammonite faunas of the Upware distract}

\section{The perisphinctid faunas of the Upware 'Corallian'}

\section{Three}

distinct Perisphinctes populations can be recognized within the Upware ‘Corallian' sequence:

P1. The fauna of the Dimmock's Cote Marl Member consists of microconch species of the subgenus Otosphinctes (P. (O.) ouatius, P. (O.) arkelli) and large Kranaosphinctesstyle macroconchs $(P$. (K.) ariprepes) showing a gradual development of variocostation. The presence also in the higher beds of forms comparable to $P$. (K.) maximus and $P$. (P.) tumulosus suggests that this may represent a separate fauna, but insufficient material is presently available to be certain of any stratigraphical distinction, and the recognition of separate faunas (P1a and P1b) must be regarded as provisional.

$P 2$. Bed 6, the basal unit of the Upware Limestone Member, contains species of the microconch subgenus Dichotomosphinctes (P. (D.) antecedens, P. (D.) buckmani) plus species of the macroconch subgenus Perisphinctes s.S. (P. (P.) parandieri, $P$. (P.) tumulosus), which form a second very distinct fauna. The large size of the microconchs, with their rectangular whorl section, is very characteristic of Dichotomosphinctes, whereas the rapid development of variocostation and extremely depressed venter around the beginning of the body-chamber in the macroconchs indicates fully developed Perisphinctes s.s. Occasional specimens, however, still show the rounded whorl section of the inner whorls more distinctive of Otosphinctes/Kranaosphinctes.

P3. In Bed 9 of the Upware Limestone, forms comparable with $P$. (D.) dobrogensis are present, distinguished from $P$. (D.) antecedens by the finer ribbing on the body chamber and the gentle forward swing of the secondaries over the venter. Macroconchs are represented by $P$. (P.) chloroolithicus and $P$. (P.) holtonensis, with onset of variocostation much earlier than in Crinoid Bed (beds 6b-c) specimens.

\section{Position of the Upware faunas within the zonal and subzonal schemes for the Sub-Boreal and Sub-Mediterranean Middle Oxfordian}

The subdivision of the English Middle Oxfordian into chronozones and subchronozones, as defined in this Sub-Boreal area, follows Callomon (1960), as modified by Sykes \& Callomon (1979). The use of chronozones rather than biozones follows Callomon (2003). Two zones, the Plicatilis and Pumilus zones, are subdivided into the Vertebrale and Antecedens subchronozones, and the Parandieri and Nunningtonense subchronozones, respectively (Fig. 15).

The Vertebrale Subzone is well known. Two distinct faunas are present. In the lower Vertebrale Subchronozone, characterized by the Dorset Preston Grit and the Yorkshire Hambleton Oolite, Upper Leaf (Wright 1997), cardioceratids markedly outnumber perisphinctids. Generally, Vertebriceras is rare, Subvertebriceras, Cardioceras s.s. and Scoticardioceras making up much of the fauna, with perisphinctids represented by P. (Liosphinctes) plicatilis (J. Sowerby), P. (Kranaosphinctes) ariprepes and $P$. (Otosphinctes) ouatius. In the upper Vertebrale Subzone, characterized by Bed 6 of the Highworth Limestone of Highworth (Arkell 1927) and the Seamer Snake Bed of Yorkshire (Wright 1972; Wright \& Rawson 2014), Kranaosphinctes, Otosphinctes and Liosphinctes occur in abundance, with occasional $P$. (Kranaosphinctes) maximus and $P$. (O) arkelli. Scoticardioceras and Subvertebriceras continue. Vertebriceras is common around Oxford, but rare elsewhere. Callomon (1960) suggested that Goliathiceras and Aspidoceras were confined to the subzone, but records from Upware and Yorkshire show that both continue into the Antecedens Subzone, and Aspidoceras into the Parandieri Subzone.

Following its introduction by Callomon (1960), the Antecedens Subchronozone has caused problems for subsequent workers (Głowniak 2002). The problem is that the time period represented by Callomon's Antecedens Subchronozone represents the acme of the subgenera Kranaosphinctes and its microconch counterpart Otosphinctes, and also of Liosphinctes spp., which are all very distinct from the subzonal index $P$. (D.) antecedens. $P$. antecedens is grouped in Dichotomosphinctes, and this, with its macroconch counterpart Perisphinctes s.s., represents 
only a part of the Antecedens Subchronozone fauna; they only become a dominant element of the fauna in the overlying Parandieri Subchronozone. Thus, beds that have yielded only a few $P$. antecedens must be allocated to the Antecedens Subchronozone, and beds such as the Crinoid Bed, which yield numerous $P$. antecedens, must be allocated to the Parandieri Subchronozone. However, this was a problem inherent in the scheme when it was set up and Callomon (personal communication, 1997) has said that he could see no reason to change the current scheme.

Though Callomon (1960) did not designate a type section for the Antecedens Subchronozone, the Headington Shell Bed in the Beckley Sand Member of Headington or Magdalen Quarry, Oxford (Wright \& Cox 2001), may be taken as typical. About equal proportions of Otosphinctes $[\mathrm{m}] /$ Kranaosphinctes [M] and Dichotomosphinctes [m]/Perisphinctes s.s. [M] are present, $P$. (O.) arkelli and $P(K$.) pickeringius plus $P$. (D.) buckmani and $P$. (P.) tumulosus being prominent (Arkell 1935-1948). Though Callomon (1960) suggested that the Headington Shell Bed might be condensed, with a number of Vertebrale Subchronozone cardioceratids being present, the bulk of the Headington perisphinctids seem undoubtably to give a proper representation of an Antecedens Subchronozone fauna. Even if the Headington Shell Bed is discounted, the fauna of the Highworth Limestone, Bed 8, of Highworth Quarries is very similar (Callomon 1960), with P. (O.) spp. and $P$. (K.) spp. plus $P$. (D.) spp. and $P(P$.) spp. all recorded (Arkell 1935-1948).

The situation in the Jura is very similar (Enay 1966). Enay was able to recognize the Antecedens Subchronozone of the Plicatilis Chronozone with abundant Kranaosphinctes and Otosphinctes in addition to $P$. (D.) antecedens, overlain by the Parandieri Subchronozone with a fauna containing numerous $P$. s.s. and Dichotomosphinctes.

Similarly, a mixed fauna is present is the Upper Heersum Beds and Lower Korallenoolith in Germany. From the former, Arkell (1935-1948) recorded numerous species of Kranaosphinctes, plus $P$. (O.) arkelli, $P$. (D.) antecedens, $P$. (D.) buckmani, and $P$. (P.) tumulosus and $P$. (P.) parandieri, a mixture of forms which is so typical of the Antecedens Subchronozone shell beds around Oxford for instance (Callomon 1960). Głowniak (2006b) attempted to confine all records of Kranaophinctes and Otosphinctes to only a part of the Upper Heersum Beds, with the replacement of these subgenera by $P$. (D.) antecedens, and presumably also by Perisphinctes s.s., in the very highest Heersum Beds. However, even in the overlying Lower Korallenoolith, Arkell recorded Kranaosphinctes spp. in addition to $P$. (D.) antecedens. Both the Upper Heersum Beds and the Lower Korallenoolith clearly contain typical mixed Antecedens Subchronozone faunas. Głowniak $(2006 a, b)$ proposed that the disappearance of Kranaosphinctes/Otosphinctes, and its replacement by Dichotomosphinctes/Perisphinctes s.s., marked the Plicatilis-Transversarium chronozonal boundary in Europe. This position is clearly untenable, as Otosphinctes/Kranaosphinctes occur together with Dichotomosphinctes/Perisphinctes s.s. at so many localities in Britain, France and Germany.

In Poland, therefore, Głowniak (2002) was unable to use Callomon's (1960) scheme, as P. antecedens and P. s.s. are unknown in beds that are apparently equivalent in age to Callomon's Antecedens Subzone. Glowniak (2002) subdivided the Plicatilis Chronozone by means of species of Otosphinctes (P. (O.) patturattensis, P.(O.) ouatius and $P$. (O.) arkelli). The Polish Arkelli Subzone is almost the direct equivalent of Callomon's Antecedens Subchronozone (Fig. 15), and $P$. arkelli is commonly found in these beds in England. The base of the Polish Transversarium Zone correlates with the lower part of the Pumilus Zone (Fig. 15). It is marked by the incoming in Poland of P. s.s. and Dichotomosphinctes (Glowniak's Buckmani Subzone).

Concerning the Upware succession, fauna P1 of the Dimmock's Cote Marl may belong to the Antecedens Subchronozone, Perisphinctes s.s. apparently making an early appearance alongside Kranaosphinctes and Otosphinctes. Fauna P2, the Crinoid Bed fauna, with its abundance of P. S.s. and Dichotomosphinctes, clearly belongs to the Parandieri Subchronozone. There is some indication of a change between Bed 6 and Bed 9, the Crinoid Bed (beds 6b-c) containing the moderately finely ribbed $P$. (D.) buckmani and $P$. (D.) antecedens, with the squarewhorled $P$. (P.) tumulosus and $P$. (P.) parandieri as macroconchs, and Fauna P3 from Bed 9 containing the finely ribbed $P$. (D.) aff. dobrogensis, with the extremely depressed-whorled P. chloroolithicus and P. holtonensis as macroconchs. However, such a distinction is not seen in the Jura (Enay 1966), where densely ribbed Dichotomosphinctes spp. occur already in the Antecedens Subchronozone.

The Parandieri Subchronozone is thus marked by a reduction in importance of Kranaosphinctes morphs (very few are known), though Kranaosphinctes-like forms come into prominence in the later Nunningtonense Subchronozone of the Upper Calcareous Grit of Laysthorpe Quarry, Yorkshire (Wright 1996), as well as in the Upper Oxfordian Cautisnigrae Subchronozone of the Clavellata Formation of Dorset (Arkell 1935, 1937a), and in the Pseudocordata Chronozone of the Westbury and Marston Ironstones of Wiltshire (Arkell 1948; Wright 2003). These specimens are now regarded as forming a distinct group within Perisphinctes s.s. (Wright \& Głowniak, in prep. 2015).

The higher part of the Polish Transversarium Chronozone comprises an Elizabethae Subchronozone (index: P. (D.) elizabethae de Riaz); although clearly postdating Bed 9 at Upware, there are suggestions that elements of this fauna may be recognizable in the Upper Calcareous Grit of North Yorkshire (Wright 1996, p. 444, pl. 2, figs 2-3, pl. 4, fig. 3) and a tentative correlation of at least the higher part of the Elizabethae Subchronozone with the Boreal Upper Oxfordian Ilovaiski Subchronozone can be proposed (Głowniak 2006a).

\section{Biohorizons}

The sequence of early Middle Oxfordian ammonite faunas revealed by the new excavations at Upware provides valuable new detailed stratigraphic and taxonomic information. For the first time in Britain, a clear sequence of three or possibly four biohorizons (sensu Page 1995) can be recognized at this level (cardioceratid data from Wright \& Page 2006). 
Plicatilis Chronozone, Arkelli Subchronozone (Central Sub-Mediterranean); Plicatilis Chronozone, Antecedens Subchronozone (Sub-Boreal); Densiplicatum Chronozone, Q: 5] Maltonense Subchronozone (Boreal)

Ia. $P$. ariprepes Biohorizon.

Index: Perisphinctes (Kranaosphinctes) ariprepes Buckman.

Reference: Bed 1, Dimmock's Cote Marl Member, West Walton Formation, Dimmock's Cote Quarry, Upware.

Fauna: poorly characterized but includes giant typical Kranaosphinctes comparable to the type of $K$. ariprepes (Arkell 1939, pl. 24, figs 5a, b).

Ib. C. sopotense - P. aff. maximus Biohorizon.

Indices: Cardioceras (Miticardioceras) sopotense (Malinowska) and Perisphinctes (Kranaosphinctes) sp. aff. maximus (Young \& Bird).

Reference: beds 2-4, Dimmock's Cote Marl Member, West Walton Formation, Dimmock's Cote Quarry, Upware.

Fauna: Perisphinctes (Otosphinctes) aff. arkelli and $P$.(O.) ouatius are common; P. (Kranaosphinctes) is frequent, including forms resembling both $P$. (K.) ariprepes Buckman and $P$. (K.) maximus (Young \& Bird), and forms close to $P$. (P.) tumulosus. C. (M.) sopotense is abundant with rare $C$. (Miticardioceras) tenuiserratum (Oppel); other cardioceratids include $C$. (Cawtoniceras) cawtonense (Blake \& Hudleston) and C. (Subvertebricereas) zenaidae (Ilovaisky). Rare Neocampylites sp. aff. henrici (d'Orbigny).

Transversarium Chronozone, 'Buckmani Subchronozone' (sensu Głowniak 2002) (Sub-Mediterranean); Pumilus Chronozone, Parandieri Subchronozone (Sub-Boreal); Tenuiserratum Chronozone, Tenuiserratum Subchronozone (Boreal).

II. P. tumulosus Biohorizon.

Index: Perisphinctes (P.) tumulosus Buckman.

Reference: beds 6a-c, Upware Limestone Member, West Walton Formation, Dimmock's Cote Quarry, Upware.

Fauna: frequent $P$. (P.) tumulosus and $P$. (P.) parandieri $[\mathrm{M}]$, with numerous $P$. (D.) antecedens and $P$. (D.) buckmani $[\mathrm{m}]$, rare $P$. (Kranaosphinctes) $[\mathrm{M}]$ and $P$. (Otosphinctes) [m], Cardioceras spp. including C. (Scoticardioceras) excavatum (J. Sowerby), C. (Maltoniceras) maltonense (Young \& Bird), C. (M.) highworthense Arkell, $C$. (Cawtoniceras) cawtonense (Blake \& Hudleston), $C$. (Subvertebriceras) densiplicatum Boden, C. (S.) zenaidae Ilovaiski and rare $C$. (Miticardioceras) sopotense and $C$. (M.) tenuiserratum.

Transversarium Chronozone, Elizabethae/Luciaeformis subchronozones (Submediterranean); Pumilus Chronozone, Parandieri Subchronozone (Sub-Boreal); Tenuiserratum Chronozone, Tenuiserratum Subchronozone (Boreal)

III. P. aff. dobrogensis-C. tenuiserratum Biohorizon.

Indices: Perisphinctes (Dichotomosphinctes) aff. dobrogensis Simionescu and Cardioceras (Miticardioceras) tenuiserratum (Oppel).

Reference: Bed 9, Upware Limestone Member, West Walton Formation, Dimmock's Cote Quarry, Upware.

Fauna: P. (P.) chloroolithicus is common along with $P$. (P.) holtonensis [M], with $P$. (D.) aff. dobrogensis. $C$. (Miticardioceras) tenuiserratum is common, and other cardioceratids include rare C. (M.) aff. sopotense, also $C$.
(Maltoniceras) maltonense, C. (Subvertebriceras) densiplicatum, C. (S.) zenaidae and C. (Cawtoniceras) cawtonense. Rare Aspidoceras (Euaspidoceras) sp. aff. paucituberculatum Arkell and Neocampylites sp. aff. henrici (d'Orbigny).

\section{Concluding remarks}

The sequence at Upware is instructive as, virtually uniquely, it contains a mixture of Boreal forms and forms that spread from the Sub-Boreal Province into the Sub-Mediterranean Province. It therefore has great potential for aiding the construction of correlative links ('tie lines') between two distinct ammonite provinces, and resolving some of the outstanding questions of European Middle Oxfordian stratigraphy. The succession is also of great importance within Britain as it is the only known locality to yield a sequence of common faunas that are stratigraphically intermediate between the classic Corallian assemblages of Oxford, described by Arkell (1935-1948), and the later faunas of the Upper Calcareous Grit of Yorkshire, described by Wright (1996).

The importance of the Upware faunas in providing such links and increasing the understanding of the nature of the sequence of ammonite faunas in the rather disjointed and locally incomplete sequences of the British Middle Oxfordian cannot be overstated. The new stratigraphical information derived, and the correlations now possible, will significantly aid inter-regional and international studies of the complex history of Middle Oxfordian sedimentation and tectonics in northern and western Europe.

\section{Acknowledgements and Funding}

Thanks are due to the helpful staff at Wicken Lime \& Stone Co. for access to the quarry, and for assistance in collecting data and specimens, including pumping out deep sumps. Thanks are also due to Matt Riley, Mike Dorling and Rod Long of the Sedgwick Museum for assistance and the loan of specimens. The late Professor J.H. Callomon reviewed an earlier version of this manuscript, and careful note has been taken of his comments. The authors also wish to thank Dr Ewa Głowniak (University of Warsaw, Poland) and Dr Guillermo Meléndez (University of Zaragoza, Spain) for valuable discussion on the identity and correlations of the perisphinctid faunas. Thanks are also due to the very careful refereeing by Beris Cox, John Cope and Peter Rawson, which has significantly improved the manuscript. The figures were drawn by Lynne Blything. Photographs were taken by Kevin d'Souza.

\section{Scientific editing by Peter Rawson}

\section{References}

Arkell, W.J. 1927. The Corallian rocks of Oxford, Berkshire and North Wiltshire. Philosophical Transactions of the Royal Society, 216, 67-181.

Arkell, W.J. 1935-1948. The ammonites of the English Corallian Beds. Monograph of the Palaeontographical Society, London. 1935, Part 1, Issue 398, (part of Volume 88), pp. i-xxxii, 1-30, pls A, B, 1-6; 1936, Part 2, Issue 402, (part of Volume 89), pp. xxxiii-xlvi, 31-42, pls C, D, 7-10; 1937, Part 3, Issue 406, (part of Volume 90), pp xlvii-liv, 43-67, pls E, F, 11-13, index; 1938, Part 4, Issue 410, (part of Volume 91), pp. 69-104, pls 14-18; 1939, Part 5, Issue 417, (part of Volume 93), pp. lv-lxiv, 105-190, pls 1940; 1940, Part 6, Issue 418 (part of Volume 94), pp. 1xv-1xxii, 191-216, pls 41-47; 1941, Part 7, Issue 423 (part of Volume 95), pp. lxxiii-lxxx, 217-238, pls 48-51; 1942, Part 8, Issue 426(part of Volume 96), pp. 239-254, pls 5255; 1943, Part 9, Issue 429 (part of Volume 97), pp lxxxi-lxxxiv, 255-268, pls 56-60; 1945, Part 10, Issue 431 (part of Volume 98), pp 269-296, pls 61-66; 1946, Part 11, Issue 435 (part of Volume 99), pp 297-332, pls 67-70; 1947, Part 12, Issue 438 (part of Volume 100), pp 333-350, pls 71-74; 1947, Part 13, Issue 442 (part of Volume 101), pp 351-378, pls 75-78; 1948, Part 14, Issue 445 (part of Volume 102), pp i-v, 379-420, title page and index.

Arkell, W.J. 1936b. The ammonite zones of the Upper Oxfordian of Oxford, and the horizons of the Sowerby's and Buckman's types. Quarterly Journal of the Geological Society of London, 92, 146-187.

Arkell, W.J. 1937b. The zonal position of the Elsworth Rock, and its alleged equivalent at Upware, Cambridgeshire. Geological Magazine, 74, 445-458. 
Besenov, N.V. \& Michailova, I.A. 1983. The evolution of the JurassicCretaceous ammonoids. Doklady Akademii Nauk SSSR, 269, 733-737.

Besnosov, H.V. \& Mitta, V.V. 1995. Oxfordian ammonites from Central Asia. Privately printed by the authors, Moscow. (In Russian.)

Bonarelli, G. 1894. Contributo alla conoscenzo del Giura-Lias Lombardo. Atti reale Accademica della Scienze Torino, 30, 18

Buckland, W. 1836. Geology and mineralogy considered with reference to natural theology. Bridgewater Treatise, $\mathbf{6 , 2}$ vols.

Buckman, S.S. 1920-1921. Type ammonites, 3. Published by the author, London and Thame, 5-48.

Buckman, S.S. 1923-1925. Type ammonites, 5. Published by the author, London and Thame, 5-48.

Buckman, S.S. 1925-1927. Type ammonites, 6. Published by the author, London and Thame, 1-61.

Buckman, S.S. 1927-1928. Type ammonites, 7. Published by the author, London and Thame, 1-78.

Callomon, J.H. 1960. New sections in the Corallian Beds around Oxford, and the subzones of the Plicatilis Zone. Proceedings of the Geologists' Association, 71, 177-208.

Callomon, J.H. 1963. Sexual dimorphism in Jurassic ammonites. Transactions of the Leicester Literary and Philosphical Society, 57, 21-56.

Callomon, J.H. 1973. On Campylites Rollier, 1922, and Neoprionoceras Spath, 1928 (Ammonoidea. Jurassic). Journal of Palaeontology, 47, 1003.

Callomon, J.H. 1981. Dimorphism in ammonoids. In: House, M.R. \& Senior, J.R. (eds) The Ammonoidea. Systematics Association Special Volume Academic Press, London, 18, 257-273.

Callomon, J.H. 1985. The evolution of the Jurassic ammonite family Cardioceratidae. In: Cope, J.C.W. \& Skelton, P.R. (eds) Evolutionary Case Histories From the Fossil Record. Special Papers in Palaeontology. The Palaeontological Association, London, 33, 49-90.

Callomon, J.H. 2003. Stratigraphic procedure - an essay review. Proceedings of the Geologists' Association, 114, 263-269.

Cariou, E., Enay, R., Atrops, F., Hantzpergue, P., Marchand, D. \& Rioult, M 1997. In: Cariou, E. \& Hantzpergue, P. (eds) Biostratigraphie du Jurassique Ouest-Européen et Méditerranéan: zonations parallèles et distribution des invertébrés et microfossiles. Bulletin Centre Recherche Elf-Exploration Production, Mémoire Oxfordien, 17, 79-86.

Chandler, R. \& Callomon, J.H. 2009. The Inferior Oolite at Coombe Quarry, near Mapperton, Dorset, and a new Middle Jurassic ammonite fauna horizon, Aa-3b, Leioceras comptocostosum n.biosp. in the Scissum Zone of the Lower Aalenian. Proceedings of the Dorset Natural History and Archaeological Society, 130, 99-132.

Choffat, P. 1893. Description de la faune Jurassique du Portugal. Classe des Céphalopodes. 1. Ammonites du Lusitanien de la Contrée de Torres-Vedras. Imprimerie de 1'Académie Royale des Sciences, Lisbonne, 1-82.

Cope, J.C.W. 1967. The palaeontology and stratigraphy of the lower part of the Upper Kimmeridge Clay of Dorset. Bulletin of the British Museum (Natural History), Geology Series, 15, 1-79, pls 1-33.

Dommergues, J.L., Page, K.N. \& Meister, C. 1996. A detailed correlation of Upper Sinemurian (Lower Jurassic) ammonite biohorizons between Burgundy (France) and Britain. Newsletters on Stratigraphy, 30, 61-73.

Dorn, P. 1930. Die Ammoniten-Fauna des untersten Malm der Frankenalb. 1, Die Perisphincten. Palaeontographica, 73, 107-172.

Enay, R. 1966. L'Oxfordien dans la moitié sud du Jura Français. Nouvelles Archives du Muséum d'Histoire naturelle de Lyon, 8, 1-323.

Fernandez-Lopez, S. 1995. Taphonomie et interpretation des paléoenvironments. Geobios, M.S. 18, 137-154.

Fisher, J.-C., (ed.) 1994. Révision critique de la Paléontologie Française d'Alcide d'Orbigny, I Céphalopodes Jurassiques. Masson \& Muséum National d'Histoire Naturelle, 338

Głowniak, E. 2000. The Platysphinctes immigration event in the Middle Oxfordian of the Polish Jura Chain (Central Poland). Acta Geologica Polonica, 50, 143-160.

Głowniak, E. 2002. The ammonites of the family Perisphinctidae from the Plicatilis Zone (lower Middle Oxfordian) of the Polish Jura Chain (Centra Poland); their taxonomy, phylogeny and biostratigraphic value. Actc Geologica Polonica, 52, 307-364.

Głowniak, E. 2006a. Correlation of the zonal schemes at the Middle-Upper Oxfordian (Jurassic) boundary in the Submediterranean province: Poland and Switzerland. Acta Geologica Polonica, 56, 33-50.

Głowniak, E. 2006b. The Platysphinctes immigration event: Biostratigraphic and palaeobiogeographic implications for the middle Oxfordian (Late Jurassic) seas of Central Europe (N.W. Germany, Poland). Neues Jahrbuch für Geologie und Paläontologie Abhandlungen, 241, 155-201.

Głowniak, E. \& Wierzbowski, A. 2007. Taxonomical revision of the perisphinctid ammonites of the Upper Jurassic (Plicatilis to Planula zones) described by Jósef Siemiradzki (1891) from the Kraków Upland. Volumina Jurassica, 5, 31-137.

Gümbel, C.W. 1865. Geognostische Verhältnisse der Fränkischen Alb. In Riehl, W.H. von (ed.) 1860-1868, Bavaria: Landes- und Volkskunde des Königreichs Bayern. Cotta, Munich, 3, 751-824.

Gümbel, C.W. 1891. Geognostische Beschreibung der Fränkischen Alb (Frankenjura). Geognostische Beschreibung des Königreichs Bayern, 4, 121.

Gygi, R.A. 1990. Oxfordian ammonite succession near Liesberg BE and Péry $\mathrm{BE}$, northern Switzerland. Eclogae geologicae Helvetiae, 83, 177-199.
Gygi, R.A. 1995. Datierung von Seichtwassersedimenten des Späten Jura in der Nordwestschweiz mit Ammoniten. Eclogae geologica Helvetica, 88, 1-58.

Kelly, S.R.A. 1985. Jurassic and Cretaceous deposits of Upware, Cambridgeshire (a review and excursion report). Bulletin of the Geological Society of Norfolk, 35, 3-38

Kennedy, W.J. 2006. John Michael ('Jake') Hancock (1928-2004): A personal memoir. Proceedings of the Geologists' Association, 117, 103-122.

Kennedy, W.J. \& Cobban, W.A. 1976. Aspects of ammonite biology, biogeography and biostratigraphy. Special Papers in Palaeontology, 17. The Palaeontological Association, London.

Klebelsberg, R. von 1912. Die Perisphinctiden des Krakauer Unteroxfordien Beiträge zur Paläontologie Österreich-Ungarns, 25, 151-222.

Lehman, U. 1981. The Ammonites, Their Life and Their World. Cambridge University Press, Cambridge. (Translated by J. Lettau)

Loriol, P. De 1902-1904. Étude sur les mollusques et brachiopodes de l'Oxfordien supérieure et moyen du Jura lédonien. Mémoire du Societé Paléontologique Suisse, 29-31, 1-298.

Makowski, H. 1963. Problem of sexual dimorphism in ammonites Palaeontologica Polonica, 12, 1-92.

Makowski, H. 1971. Some remarks on the ontogenetic development and sexual dimorphism in the Ammonoidea. Acta Geologia Polonica, 21, 321-340.

Malinowska, L. 1963. Stratigraphy of the Oxfordian of the Czestochowa Jurassic on the basis of ammonites. Biuletyn Instytutu Geologicznego Warsawa, $\mathbf{3 6}$ 1-165. (With English text.)

Malinowska, L. 1972. The Middle Oxfordian Perisphinctidae of Zawodzie nea Czestochowa (Poland). Acta Palaeontologica Polonica, 17, 167-242. (With English text.)

Matyja, B.A. 1977. The Oxfordian in the southwestern margin of the Holy Cross Mountains. Acta Geologica Polonica, 27, 1-64.

Matyja, B.A. \& Głowniak, E. 1994. The ammonite succession of the Plicatilis and Transversarium Zones in the Submediterranean Middle Oxfordian of Poland. In: Atrops, F. (ed.) 4th Oxfordian and Kimmeridgian Working Group Meeting, Lyon and southeast France. June 13-18, 1994. Guide Book and Abstract, University of Lyon, 11-12

Meléndez, G., Atrops, F., Bello, J., Brochwicz-Lewiiski, W., Fözy, I., Pérez-Urresti, I., Ramajo, J. et al. 2009. The Oxfordian ammonite genus Passendorferia Brochwicz-Lewinski and the Tethyan subfamily Passendorferiinae Meléndez: Origin and palaeobiogeography. Volumina Jurassica, 7, 113-134

Oppel, A. 1862-1863. Über Jurassische Cephalopoden. Paläontologische Mittheilungen aus dem Museum des königlich bayerischen Staates, part iii, 127-162 (1862), 162-266 (1863). Ebner \& Seubert, Stuttgart.

Orbigny, A. D' 1850. Paléontologie Française: Terrain Jurassique. 1 Céphalopodes. Victor Masson, Paris. Livr, 55-62, 521-632.

Page, K.N. 1986. A new section in the Elsworth Rock (Jurassic, Oxfordian) at Papworth Everard, near Cambridge, England. Proceedings of the Geologists Association, 97, 229-235

Page, K.N. 1995. Biohorizons and Zonules: Intra-Subzonal units in Jurassic ammonite stratigraphy. Palaeontology, 38, 801-814.

Page, K.N. 1996. Mesozoic ammonoids in time and space. In: Landman, N.H., Tanabe, K. \& Davis, R. (eds) Ammonoid Palaeobiology. Plenum Press, 855-794.

Page, K.N. 2008. The evolution and geography of Jurassic ammonites Proceedings of the Geologists' Association, 119, 35-57.

Riaz, A.De 1898. Description des Ammonites des Couches à Peltoceras trans versarium (Oxfordien supérieur) de Trept (Isère). Paris and Lyon.

Roberts, T. 1892. The Jurassic Rocks of the Neighbourhood of Cambridge. Sedowick Prize Essay for 1886. Cambridge University Press, Cambridge.

Salfeld, H. 1914. Über einige stratigraphisch wichtige und einige seltene Arten der Gattung Perisphinctes aus dem oberen Jura Nordwestdeutschlands. Jahresberichte des nieder Sächsischen geologischen Vereins, 67, 231-251.

Siemiradzski, J. 1899. Monographische Beschreibung der Ammonitengattung. Perisphinctes. Palaeontographica, 14, 69-352

Simionescu, I. 1907. Studii Geologice şi Paleontologice din Dobrogea. 1. Fauna cefalopodelor jurasice dela Harşova. Academia Română Publicatiunile Fondului Vasile Adamachi, 21, 1-97.

Sowerby, J. 1812-1822. The Mineral Conchology of Great Britain. London.

Spath, L.F. 1928. Revision of the Jurassic cephalopod fauna of Kachh (Cutch) part ii. Memoirs of the Geological Survey of India (Palaeontologica Indica), 9, Mem. 2.

Spath, L.F. 1931. Revision of the Jurassic cephalopod fauna of Kachh (Cutch) parts iv and v. Memoirs of the Geological Survey of India (Palaeontologica Indica), 9, Mem. 2 .

Steinmann, G. 1890. Elemente der Paläontologie bearbeitet : von Dr. Gustav Steinmann und Dr. Ludwig Döderlein. Engelmann, Leipzig, 848.

Sykes, R.M. \& Callomon, J.H. 1979. T he Amoeboceras zonation of the Boreal Upper Oxfordian. Palaeontology, 22, 839-903

Waagen, W. 1869. Die Formenreihe des Ammonites subradiatus. Benecke's Geognotische-Paläontologische Beitrage, Munich, 2. Heft, 2, 181-256.

Wright, J.K. 1972. The stratigraphy of the Yorkshire Corallian. Proceedings of the Yorkshire Geological Society, 39, 225-266.

Wright, J.K. 1996. Perisphinctid ammonites of the Upper Calcareous Grit (Upper Oxfordian) of North Yorkshire. Palaeontology, 39, 433-469.

Wright, J.K. 1997. Cardioceratid ammonites from the Middle Oxfordian Vertebrale Subzone of North Yorkshire and Dorset. Proceedings of the Yorkshire Geological Society, 51, 251-258.
1653 


\section{K. N. Page et al.}

Wright, J.K. 2003. New exposures of the Ampthill Clay near Swindon, Wiltshire, and their significance within the succession of the Oxfordian/ Kimmeridgian boundary beds in southern England. Proceedings of the Geologists' Association, 114, 97-121.

Wright, J.K. 2012. Speciation in the cardioceratid ammonites of the Costicardia Subzone (Cordatum Zone) of the Oxfordian of the Isle of Skye. Scottish Journal of Geology, 48, 61-72.

Wright, J.K. \& Cox, B.M. 2001. British Upper Jurassic Stratigraphy (Oxfordian to Kimmeridgian). In: Skevington, D. (ed.) Geological Conservation Review Series No. 21. Joint Nature Conservation Committee, Peterborough.

Wright, J.K. \& Page, K.N. 2006. The cardioceratid ammonite fauna of the Upware Limestone and Dimmock's Cote Marl (Upper Jurasssic) in Cambridgeshire, England. Proceedings of the Yorkshire Geological Society, 56, 65-75.

Wright, J.K \& Rawson, P.F. 2014. The development of the Betton Farm Coral Bed within the Malton Oolite Member (Upper Jurassic, Middle Oxfordian) of the Scarborough District, North Yorkshire, UK. Proceedings of the Yorkshire Geological Society, 60, 123-134.
Wright, J.K., Kelly, S.R.A. \& Page, K.N. 2000. The stratigraphy of the 'Corallian facies' Middle Oxfordian (Upper Jurassic) deposits at Upware, Cambridgeshire. Proceedings of the Geologists' Association, 111, 97-110.

Young, G.M. \& Bird, J. 1822. A geological survey of the Yorkshire coast; describing the strata and fossils occurring between the Humber and the Tees, from the Germany Ocean to the plain of York. Whitby, 332.

Young, G.M. \& Bird, J. 1828. A geological survey of the Yorkshire coast; describing the strata and fossils occurring between the Humber and the Tees, from the Germany Ocean to the plain of York. 2nd ed. Whitby.

Zittel, K.A. 1868. Cephalopoden der Stramberger Schichten. Paläontologische Mitteilen Museum des königlisches Bayerisches Staates, 2, 33-118.

Zittel, K.A. 1881-1885. Handbuch der Palaeontologie: Abteilung I, Palaeozoologie Band II, Mollusca und Arthropoda. Oldenbourg, Munich and Leipzig, 893 .

Zittel, K.A. 1895. Grundzüge der Palaeontologie (Palaeozoologie). Oldenbourg, Munich and Leipzig, 971. 